\title{
The Foolosophy of Justice and the Enigma of Law
}

\author{
Peter Goodrich ${ }^{*}$
}

in imagine ambulat homo ${ }^{1}$

When lawyers use images in juristic texts, what is their legal meaning? Specifically, when legal texts print pictures of Justice and of Justice blindfolded, as they did particularly in the sixteenth century in legally authored emblem books and works of doctrine, then what is their significance for lawyers? And more specifically still, what is the proper interpretation of the blindfold, which we find not only on Justice (Justitia) but also on juristic representations of Cupid, Fate (Fortuna), bridegrooms, and the condemned? My answer, I will not tease or otherwise keep you waiting, is that the image of Justitia is technically an aenigma iuris, a legal symbol whose referent has been forgotten. ${ }^{2}$

My initial proof, my text, my image, will be a paradoxical one taken from a legal treatise, Barthélemy Aneau's Jurisprudentia, a somewhat hagiographical history of jurisprudence first published in 1554. My focus will be on the figure of Justitia used immediately following a textual discussion of mythological sources of legal rule and of the homines sacer, the holy interpreters of law. ${ }^{3}$ While I will show that the figure, which pictures Justitia on a pedestal, sighted and reading from a book of the laws to an audience of blindfolded lawyers, is paradoxically a didactic and moralizing excursus in political theology, there is a further

\footnotetext{
* Professor of Law, Director of Law and Humanities, Benjamin N. Cardozo School of Law, Yeshiva University.

1. Psalms 39:6 (Vulgate).

2. The term derives from ANTONIO DE NEBRIJA, AENIGMATA IURIS CIUILIS (1506), republished under differing titles in later editions. I have used a 1612 edition titled VOCABULARIUM UTRISUQUE IURIS (Venice, Zalterium 1612), For extended discussion, see Peter Goodrich, Legal Enigmas: Antonio de Nebrija, The Da Vinci Code, and the Emendation of Law, 30 OXFORD J. LEGAL STUD. 71 (2010).

3. BARTHELEMY ANEAU, JuRISPRUDENTIA 10 (Lyon, Bonhomme 1554). For a discussion of the context of the work, see Marie Madeleine Fontaine, Barthélemy Aneau et la Jurisprudentia, in ESCULAPE ET DIONYSUS: MÉlaNGES EN L'HONNEUR DE JEAN CÉARD 1001 (Jean Dupèbe et al. eds., 2008). For an extended deliberation upon the use of emblems by lawyers, see VALÉRIE HAYAERT, MENS EMBLEMATICA ET HUMANISME JURIDIQUE (2008).
} 
conundrum. ${ }^{4}$ The specific image upon which I am focusing derives from a text published a year earlier: the Toulousean lawyer Guillaume de la Perrière's Foolosophy, composed in 1552 and printed in $1553 .{ }^{5}$

The question, the issue, the recollection of what was once a commonplace, the emblem as a legal device, as a mode and medium of the theater of justice and truth, as a tool of memory and imagination, eloquence and wisdom, far outstretches the purposes of the current

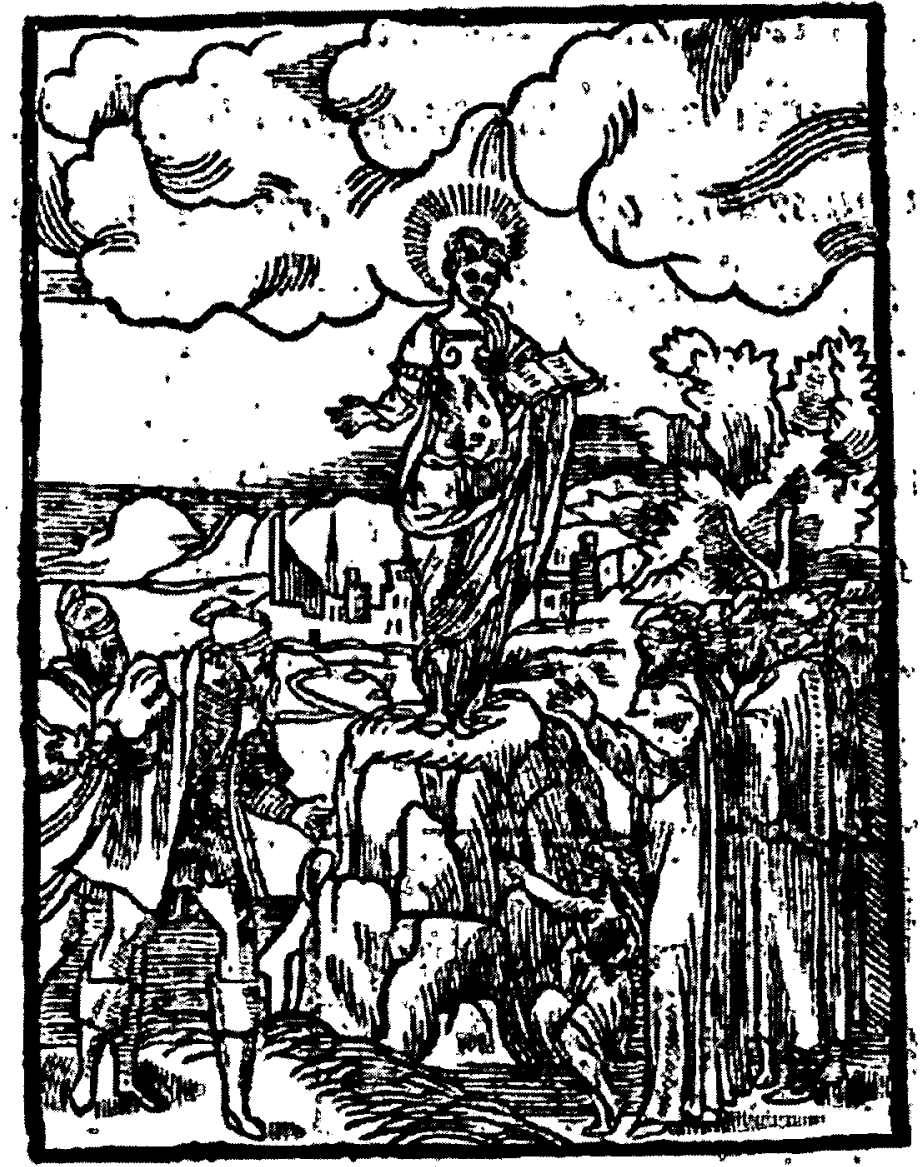

Figure 1. Emblem from Jurisprudentia, Barthélemy Aneau, page 10, 1554, Lyon, Bonhomme.

Reproduced courtesy of the Bibliothèque nationale de France.

4. Figure 1.

5. Guillaume de la Perrière, La Morosophie: contenant cent emblemes moraux, ILLUSTREZ DE CENT TESTRASTIQUES LATINS (1553). La Perrière was also author of the first vemacular emblem book, LE THÉÂTRE DES BONS ENGINS (1539/1540), which appeared later in an intriguing English adaptation by THOMAS COMBE, THE THEATRE OF FINE DEVICES (London, Field 1614). 
digression in pictorial interpretation. Nonetheless, a certain degree of context and specifically a reference to the role of images, to the visual grammar of the early modern period and its crucial facility in relaying memory and motive, genealogy and norm, are requisite. Imagesimagines agentes-were active forms, the motors of tradition and professional practice, and bore a technical meaning that derived in theory at least from the ancient art of the hieroglyph and the holy letters, the "hierographie," of a veritably antique and carefully shrouded law. "The wisest of the ancient authors," observes Giulo Camillo in the opening lines of his Theatre of Memory, "would never expose divine secrets in their writings except under cover of enigmas and veils . . . so that they could not be understood except by those whom God had chosen to apprehend the holy mysteries." These signs belong, he continues, "to the divine army, to the angelic trumpeters, to the order of the Prophets and Preachers, and are the insignia, which is to say the signs and visions which signify without expressing."

I will argue in what follows that the humanist lawyers, doctors all as they explicitly were of knowledge "divine and human," and so also of utrumque ius, a dual law, belong firmly within the tradition of hieroglyphic signs, of visual tropes and obscure figures that convey the holy knowledge and practice of law. Barthélemy Aneau expressly writes within this generously expansive humanist poetics of law, a juristic tradition that self-consciously mixes erudition and esotericism, poetry and justice, image and written law. My initial analysis will thus focus upon the legal reception and interpretation of the hieroglyphic tradition. The alphabet of images, the standard pictorial topoi that lawyers inherited and used, were drawn from the dictionaries of visual figures derived from Horapollo and Piero Valeriano, the first authors to provide a lexicon of these "Aegyptian" symbols. ${ }^{7}$ The image as it grew to be used in the ius imaginum, the law of the visual, was a complex sign variously indicating honor, title, office, and role. The heraldic device, the first form of social

6. Giulio Camillo, ThéÂtre de la Memoire 43-44 (Allia 2001) (1544). For discussion, see FRANCES YATES, THE ART OF MEMORY 129-72 (Routledge \& Kegan Paul 1966). Further inquiry into this concept would lead, I suspect, to Heraclitus and the opaque maxim that nature loves to hide, which Pierre Hadot has done so much to elaborate and translate in PIERRE HADOT, THE VEIL OF ISIS (2007). My thanks to Ruth Weisberg for reminding me of, though I must add that it is not for me so much a question here of memory as of forgetting, damnatio memoriae, that other curiosity of Roman law, that most appeals.

7. The chief sources were HORAPOLLO, THE HIEROGLYPHICS OF HORAPOLlo (George Boas trans., 1950) (1505); and PIERo VAleriano, HieroglyPHICA (Basle, Isengrin 1556). That lawyers readily took up the theme of the hieroglyphic character of knowledge is evident most obviously in NEBRIJA, supra note 2. A later example from common law is ABRAHAM FRAUNCE, SYMBOLICAE PHILOSOPHIAE LIBER QUARTUS ET ULTIMUS (AMS Press 1991) (1590), which presents a list of symbolic figures and their meanings at the end of the work. The general history of visual representations of honor can be found in the English version of Jovius, SAMUEL DANIEL, THE WORTHY TRACT OF PAULUS JOVIUS (Scholar's Facsimiles 1976) (1585). 
emblem, was a note of dignity (notitia dignitatum) which lawyers had long employed to indicate identity and jurisdiction, office and role. It belonged to a carefully transcribed tradition of enigmatic figures that had the dual purpose of identifying and concealing through that arcane mixture of classical pictorial symbols, Latin mottos and vernacular verses that came to make up the emblem tradition. I will then propose, with a crescendo of images, that the figure of Justice belongs precisely within this shrouded and dark tradition and that the emblematic usage of blindfolds and other paradoxically visual indicia is equally there in the service of enigmatic and initiate meanings. As has long been suggested by non-lawyers, the signs of law, its foreign languages, its prolixity, its convolution, and increasingly its images, are in significant measure not supposed to be understood but rather to be observed, revered, and obeyed. The images are flags, ensigns, symbola heroica, the choral identificatory insignia that a populace can follow but only the few, the iuris periti, the legally learned of whom there are ever fewer to be found today in the trade schools that generally pass for legal academies, can properly interpret and understand. ${ }^{8}$ It is necessary to take a stand in support of the importance of the visual. We have to look at the overlooked and learn to address the significance of the "visial lines," as Coke once termed it, the visible structures and plastic forms that constitute the immediate and recognized presence of law. These construct the longue durée of normativity, and relay the imaginary of justice that lawyers sometimes remember to address as the dictates of conscience. The last point to be perambulated will thus be the careful reconstruction of the specific image of Justice that Aneau uses, in its context of related legal emblems, to allow me to evidence and interpret the figure in its proper juristic place, that of a forgotten and thus subsisting political theology of law.

\section{FIGURES OF IDENTITY AND EXCLUSION}

I will start as I intend to continue, with an image, ad apparentiam, so as to provide the feel for the visual associations that will form the trajectory of what follows. Pierre Coustau's Pegma, published in 1555, is perhaps the most self-consciously juridical and most carefully annotated book of legal emblems aside from the 1531 compilation of Alciatus's Emblemata. ${ }^{9}$

8. See SiR John Ferne, The Blazon of Gentrie (London, Winder 1586); and ClaUde PARADIN, THE HEROICAL DEVICES (1557) on symbola heroica. BARTOLUS OF SASSAFERATO, TRACTUS DE INSIGNIS ET ARMIS (1358), reprinted in A GRAMMAR OF SIGNS: BARTOLO DA SASSOFERRATO'S TRACT ON INSIGNIA AND COATS OF ARMS (Osvaldo Cavallar et al. eds. \& trans., 1994), is the acknowledged source.

9. I have used ANDREAS AlciATUS, 1 THE LATIN EMBLEMS (Peter Daly ed., 1985). The various editions and vernacular interpretations can be consulted most easily and usefully at the GLASGOW UNIVERSITY EMBLEM WEBSITE, http:/www.emblems.arts.gla.ac.uk/ (last visited Nov. 16, 2011). 
Indeed the most expansive commentary on Alciatus post dates Coustau and is Mignault's Syntagma de Symbolis, published in $1577 .^{10}$ The title, the very notion of Pegma, of theatrical machines that raise and lower actors and props to the stage, already provides an excellent sense of what the Emblemata itself intends to do. ${ }^{11}$ These images enact and make present the norms that found the law. They bring the virtues of legal rule to social visibility. They show jurisprudence to be the "image of the public good." And in Coustau's case they also allow for lengthy discussions of an antique law that needs both custody and transmission to a new generation enthused by the novel technology of print. The Pegma, which provides a reasoned visual presentation of a range of emblematic norms, begins with three emblems of Justice. I select the second, "Another image of justice, after Nigidus."

The image is of Justice seated in the clouds, her head amongst the stars, her sword cleaving a path between the constellations, between Libra and Leo, the scales and the lion, as we are informed in the verse explanation that usefully follows in Latin. In emblematic argot, the image is a version of the opening injunction of the Institutes of Justinian, which declares that the Emperor is not simply honored by arms but also armed by laws. Hence the sword, symbolizing the earthly dominion of the heavenly lion, the threat of arms, the fearful force that majesty can inflict. Note also, however, the insignia that are missing. There is no scale in the left hand of Justice, nor any blindfold over her eyes. There is a band of cloth-in English emblem literature, "a skarfe"- that flows behind her and signifies chance. But she is sighted and indeed from her heavenly perspective is in a position of panopticism if not omnivoyance. Certainly according to the philosophical narration and the motto, in sordidè iudicantes, against corrupt judges, Justice looks down upon dissolution and venality. She sees the winds of chance, the rolling of Fortuna's dice that stands for human justice, and hence the band that trails behind her. Video et rideo, I look and I laugh, is one relatively common association with the heavenly eye, indicating the all powerful character of divine optics and the futility of human attempts to hide their crimes from sovereign view. The sighted Justice aloft, in nubibus, flies with a band of cloth, a flag, a potential

10. Pierre Coustau, Pegma Cum Narrationibus Philosophicis (Lyon, Bonhomme 1555).

11. HAYAERT, supra note 3 , at $49-78$, discusses a dazzling array of sources and evidences a theatrical meaning of "putting before the eyes." The theatrical is also, of course, the express setting of la Perrière's first vernacular emblem book, and Thomas Combe in his translation notes that words "do passe the Reader without due consideration," whereas devices have the virtue of "pictures that especially are discerned by the sense, are such helps to the weaknes of the common understandings, that they make words as it were deedes ...." (n.p. "To the Reader"). NEBRIJA, supra note 2, notes that "paegma" is cognate with specularia, meaning a window through which we see something raised up on high.

12. Figure 2. 
blindfold perhaps, trailing behind her. And the image serves most likely to remind the viewer of the partiality and criminality that the heavens witness in our earthly behavior. A blindfold in this context would spare Justice an unseemly sight and serve also to protect and separate the divine from the human, the heavens from the earth, portrayed so self-consciously below in the mode of barren rock and a weeping tree.

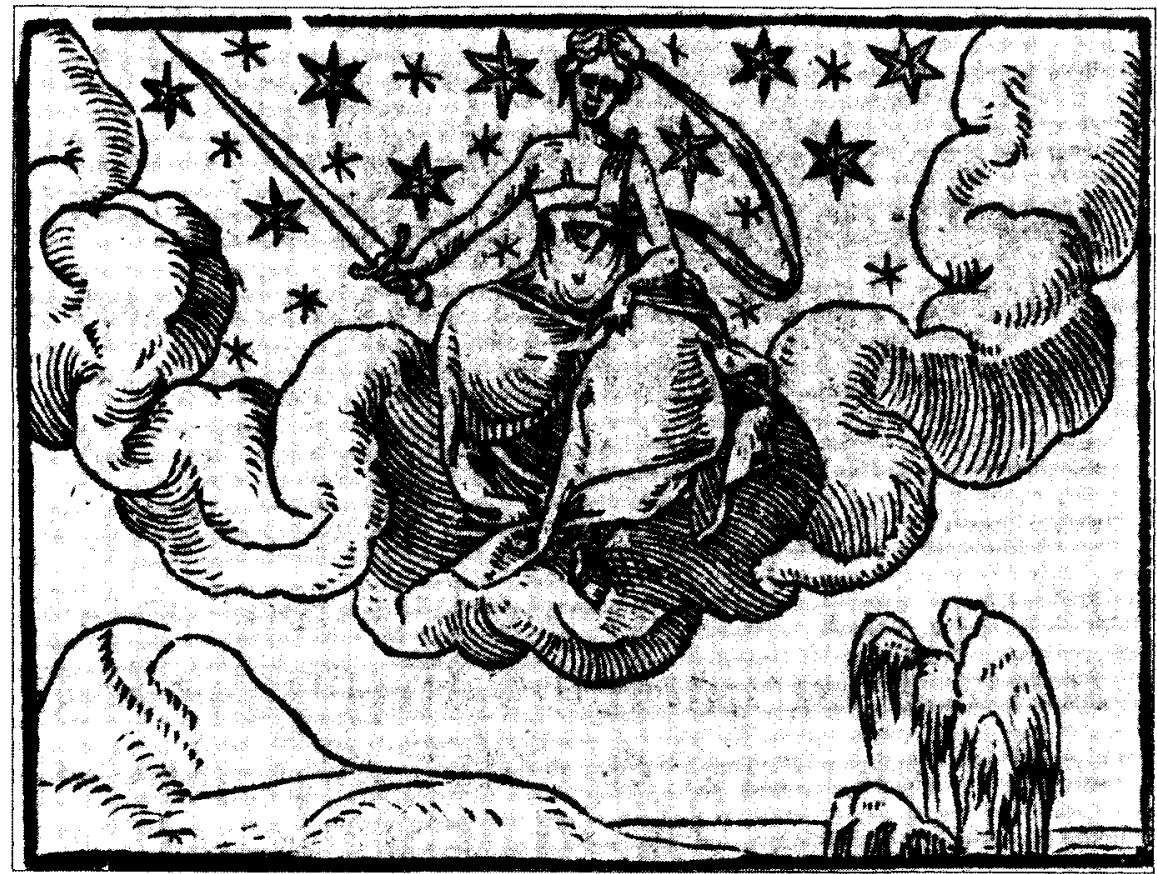

Figure 2. Emblem from Pegma: cum narrationibus philosophicis, Pierre Coustau, page a6r, 1555, Lyon, Matthias Bonhomme.

Reproduced courtesy of the Rare Book Collection, Lillian Goldman Law Library, Yale Law School.

Given that the astrological and Latin references of the emblem are opaque to all but the most well-trained viewers, the general sense of the image is of Justice as a feminine divinity on high, an apparition that represents a divine and unknowable order, an angelic chorus and heavenly sphere that cannot normally be seen, will not be comprehended, and must rather be addressed through faith, approached with reverence, and apprehended by means of awe. Our early lawyers tell us as much. We must judge, according to the fifteenth century Chief Justice Fortescue, explicitly as sacerdotes, "with downcast eyes," reverently, with the appropriate filial fear of the sacred author of laws. We are children, and God is the father to whom all reverence and glory are owed. Coustau is to the same effect, stating in his commentary that "splendor and dignity" are 
the primary attributes of sacred justice. ${ }^{13}$ Coustau's image requires-to borrow a term-"dualisis,"14 a double reading in which lawyers and divine interpreters have long been trained. The image is a site of attachment, a flag that identifies, names, and leads the group. It is also, however, veritas falsa, a false truth, which hides and deceives, if only or not least because it is not what it represents.

To represent Justice as a god, and this is hardly a novel point, is to identify but also to remove the object viewed. The divinity hides so as to veil the sources of sovereign counsel. Thus in an image of the deity Consus, this time from Guillaume de la Perrière, we see graphically represented not only the genuflection, abasement, and reverence that institute a hierarchy, but also the bars, the cancellarius, and the grill, which obscures the divinity and keeps her out, excluded from the diurnal and human. ${ }^{15}$ This visual trope of bars and separation, of the reja, of an

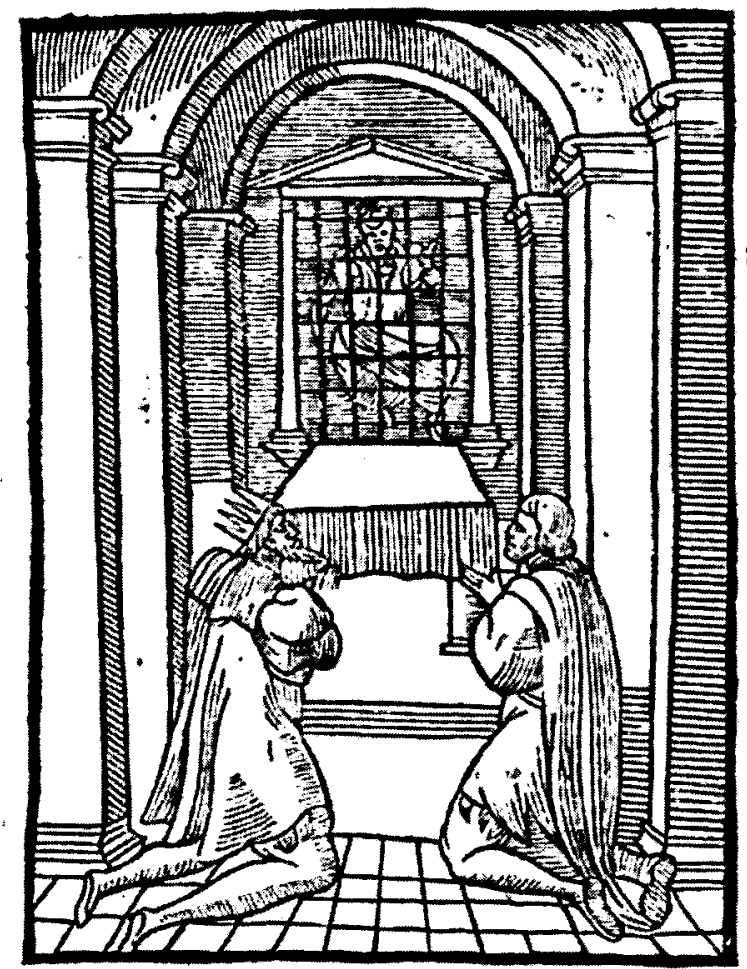

Figure 3. Emblem from La Morosophie, Guillaume de la Perrière, page 88, 1555, Lyon, Bonhomme.

Reproduced courtesy of the University of Glasgow Library, Special Collections

13. SiR John Fortescue, De Natura Legis Naturae 276 (London, Private Circulation 1869) (ca. 1460); COUSTAU, supra note 10, at a7r.

14. François LaRUElle, Future Christ: A LesSON IN HeRESy $52-54$ (2010).

15. Figure 3. 
enshrined yet exiled source of sovereign rule takes us to the question of the juristic image quite directly. The picture, the visible sign, is the most public mode of declaration of nobility, office, sovereignty, and rule. It is the subject matter of the ius imaginum, the law of images, to be sure, but best translated as law of honor, of the auratic and unseen dimensions of justice and legislation. The hieroglyphic character of legal symbols, frequently and expressly referred to in terms of the Pythagorean and Druidic roots of common law, is a reference precisely to the human condition of unsightedness, the blindness and ignorance of mortals in the face of the law of nature, and to the divine rule that the symbol encodes and veils. Legal images are not legal inventions. They are images first, mnemonic, opaque, hieratic, and hieroglyphic. They are not meant to be understood but rather to impress, to impose, and to pass on a structure of rule, a lineage of succession, a thread of legitimacy that must be viewedobserved-yet neither too fully inquired into nor too generally understood. He who does not know how to dissimulate does not know how to rule, or so our authors are fond of noting.

As the progeny of a theological order and Christian rule, the legal image is initially an image of honor, a sign of sanctity, and is owed reverence prior to any exercise in understanding. Borrowing from Nebrija's Aenigmata iuris, the image belongs initially and expressly to the iconomus, the order of ecclesiastically controlled visibilities, an iconocracy that impresses and imposes much more than it actually administrates and governs. ${ }^{16}$ The other law, be it defined as divine and natural, or immemorial and common, pre-exists and surpasses understanding. Humans, lawyers, have access only to parts of these holy notations in the dual form of pictures and symbols. First, there is the apprehension of honor and the recognition of the mediation of such auratic images, such "visible words," through the rites and ceremonies, solemnizations and choruses of the institution. For the Anglican Church, and here it is necessary to be specific, the theology of venerating an invisible source of law means recognizing that the external eye can see very little, almost nothing. This is because the eye of the body can observe only things that are, whereas the interior eye, the vision of the spirit, oculi animi, has much greater range according to Bishop John Jewel, citing the Church father Chrysostom: "the bodily eyes that see things visible, cannot do so much, as the eyes of the spirit. For these eyes are able to see the things, that be not seen, and have no being." 17 The

16. ANTONIO DE NEBRIJA, VOCABULARIUM UTRISUQUE IURIS $151 \mathrm{I}$ (Venice, Marcum Zalterium 1612) (1506). The notion of iconocracy comes from MARIE JOSÉ MONDZAIN, L'IMAGE PEUT-ELLE TUER 8 (2002) ("Ce qu'on peut nommer un iconocratie se met en place.").

17. JoHN JEWEL, A DEFENCE OF THE APOLOGIE OF THE CHURCHE OF ENGLANDE 273 (London, Wykes 1567). 
visible world is simply "a spectacle of things invisible," 18 a glass through which we see darkly, as Saint Paul famously expounds it: nunc videmus per speculum in aenigmata, tunc autem faciem ad faciem. ${ }^{19}$

The legal conception of signs follows directly from this dualytic regimen. The sign is split between iconomic and oeconomic, between iconic and symbolic elaborations. The synoptic work of the Jesuit philosopher Menestrier provides the clearest schema of this division in practice when he charts the bifurcation of "hierograpie" as between hieroglyph and symbol, picture and writing. Notes, sculptures, paintings, form the body of devices and emblems, while the symbol, the writing, the voice, is the soul. ${ }^{20}$ The visual order hides the invisible structure of causes and meanings, and in the language of the authors of the early texts on devices, the figure-the body-is a vestige, the imprint and mark of that of which it is the symbol (impress). Abraham Fraunce, author of the Lawiers Logike of 1588, puts it strikingly as follows: a symbol is by definition a mode of concealment. It is expressly a synecdoche, a part of a larger and invisible whole. ${ }^{21}$ Hence the need for the lexicon of figures that Fraunce provides at the end of his systematic treatise on Armorial insignia, emblems, hieroglyphs and symbols. The first order of the sign and the primary meaning of symbols relate thus to an invisible dominion, to a realm in which rex regnat sed non gubernat, in which choral acclamation and visible glory precede all action and use. ${ }^{22}$ Turn then to the earliest of the modern treatises on legal signs, Gerard Legh's The Accedens of Armory, first published in $1562 .{ }^{23}$ It begins, the specification is hardly necessary, with an image of Justice alongside the other virtues, with the proper accoutrements, the visual lineaments of law. More surprising and intriguing, however, is the image of the legal herald, that immediately precedes the peroration of the work in the mode of an acclamation of the "houses of honour," the earthly form of the angelic

18. James CALfHill, AN ANSWERE to the TREATISE ON THE CROSSE, at fol. 169v (London, Denham 1565) (continuing in Pauline fashion to argue that it "is a glass to behold the secret working and hidden grace of God").

19. 1 Corinthians 13:12.

20. Francois MENESTRIER, LA PhILOSOPHIE dES IMAGES COMPOSEE D'UN AMPLE RECEUIL DES DEVISES 72-73 (Paris, Caille 1682).

21. ABRAHAM FraUnCE, InSIGNIUM ARMORUM, EMblematUm, HiEROGLYPHICORUM ET SYMBOLORUM, at fol. M2r (London, Orwin 1588) (borrowing in his turn from Claude Mignault, Syntagma de symbolis, in OMNIA ANDREA ALCIATI V.C. EMBLEMATA: CUM COMMENTARIIS 71 (Antwerp, Plantin 1577)).

22. GIORGIO AGAMBEN, LE RÉGNE ET LA GLOIRE: POUR UN GÉNÉALOGIE DU GOUVERNEMENT (2008). For elaboration on the theme of power and glory, see Peter Goodrich, Specters of Law: Why the History of the Legal Spectacle has not been Written, 2 U.C. IRVINE L. REV. (forthcoming 2012).

23. GERARD LEGH, THE ACCEDENS OF ARMORY, at fol. 133r (London, Totell 1576). Legh refers to NiCHOLAS UPTON, DE STUDIO MILITARI LIBER QUATOR (London, Norton 1654) (ca. 1434) as his inspiration, along with BARTOLUS, supra note 8. 
order extant in the Inns of Court, expressly named the temples of law. ${ }^{24}$

Legh's herald is a remarkable emblem at the end of a lengthy systematization-a rational exposition-of the visual alphabet of colors, metals, animals, and figures used in the making of devises. These

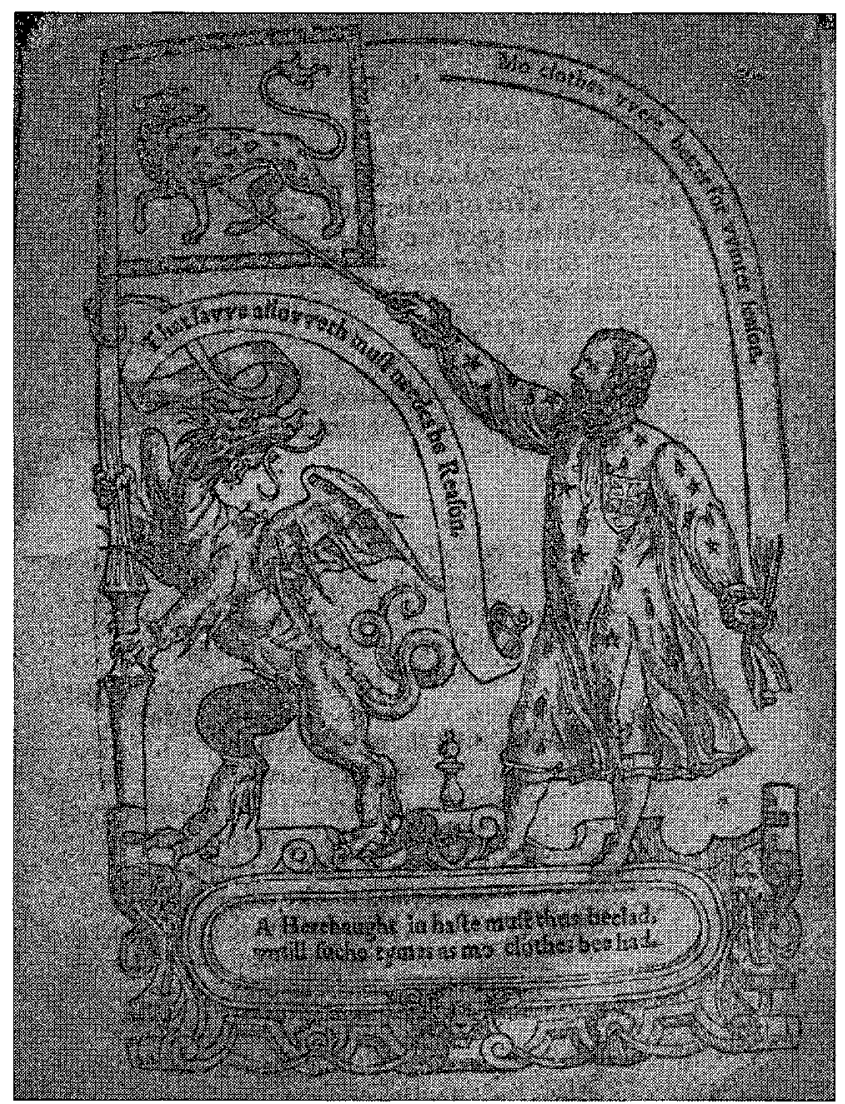

Figure 4. Emblem from The Accedens of Armory, Gerard Legh, fol. $133^{r}, 1576$, London, Totell.

Permission granted, P. Goodrich.

devices-impresa and symbols-named and identified the nobility, a word whose root is not incidentally taken to be the Latin nosco, to know. ${ }^{25}$ They are those who know more and so accommodate and present a greater dignity and louder claim of proximity to glory and, for our purposes, to the sources of sovereign rule. Be that as it may, the herald of the houses of honor, of the order of visible laws, is simply dressed. In our image he bears the royal shield on his chest and a "chemise blank" spotted with "mullets sable" (black spurs). Borrowing, or so Legh claims, from

24. Figure 4.

25. FERNE, supra note 8 , at 4. 
Bartolus, the subscript explanation indicates that what is significant is not the clothing but the message, not the person but the sign conveyed. ${ }^{26} \mathrm{As}$ for the picture itself, the herald points with the rod of office to the flag, which shows a panther, the most valued and amiable of animals. In the lexicon that Legh provides, he explains that it is this sign that is the magnet that draws all other animals to it, while the dragon, the most feared of beasts, protects the sign. The image on the flag is that of collectivity, of an identity that is to be followed, a mark of sociality, of all that is most dear and sacred and of that which has to be protected at all costs. This analysis could be extended, and should include the quotation from the maxim in the center of the emblem, familiar to Plowden and his contemporaries, which indicates that reason is law and law is reason. For Legh it is a question of legal authority guaranteeing and providing reason, in that order: law first, reason second; authority and then disposition. And we read in Coke's Institutes a comparable alignment and foundational principle of legality: "si soient en semblable reason sont en semblable ley." The bizarre law French is Coke's not mine, but translates, just to be fair to the student editors, as "if they are similar in reason they are likely law," to which it should only be added that the similarities that bind reason and law extend way beyond the merely visible. ${ }^{27}$ For what is at issue, and is always at issue for Coke, is reason true and legal not merely apparent, or in the proper and actual language of such juridical veracity "ratio vera et legalis et non apparens." 28 The reason for this, which returns ultimately to the Pythagorean and Aegyptian roots of common law symbolism, is captured well by Ovid in the maxim that the image, like the word, is always more than it seems, more than is apparent: plus est quam quod videantur imago.

The English escutcheon, the flag, the association of power with reason and law, allow for my second point. If iconomus, the order of iconic images and public evidence of divine being is a matter for the church and the higher law, an instance of glory, laudes regia and acclamation, then the order of signs, of oeconomus, is simply a vicarious and secondary expression of hierarchy and holiness. Having indicated that the flag is sacred, and that no disrespect must ever be done even to the flag, the sign, the word, of the enemy, Legh goes on to discuss honor and the house, the oeconomy with all its practicalities. One can note, along with the learned professor and antiquarian J.H. Baker, that the exemplum of the house is

26. LEGH, supra note 23, at fol. 133v.

27. The lawyer Thomas Blount, Glossographia (1656) is a useful source on the usages of the period.

28. 2 EDWARD COKE, THE FIRST PART OF THE INSTITUTES OF THE LAWS OF ENGLAND bk. III, ch. 4, § 301 (Francis Hargrave \& Charles Butler eds., Robert H. Small 1853) (1628). 
originally the royal household and oeconomy, and that the court was in the first instance the suite and following of the Crown, such that household and law court, oeconomy and law were historically proximate if not precisely synonymous. For Legh's purposes, by the mid-sixteenth century, the exemplary houses are those of lawyers, the Inns of Court, and they are modeled expressly on the heavenly hierarchy and the order of angels: "Here I might compare your state (but that you are men) unto the heavenly Ierarches, for that you have the three thinges that Ierarches have, that is, Order, cunning and working." ${ }^{29}$ It is in this context that we need to understand the legal use and meaning of images as the form of transmission and passage between iconomy and oeconomy, whereby the meaning of the icon is reiterated in the lawyer's devices, pictures, and emblems-sacrae notae all. The lawyers partake of the iconic and embody the images of the virtues in the emblems of law. And so, without further background digression, how is the enigma of Justice initially to be understood?

Legh instances Justice as one of the four founding virtues that establish the commonwealth of signs. ${ }^{30}$ The frontispiece shows Moses handing a

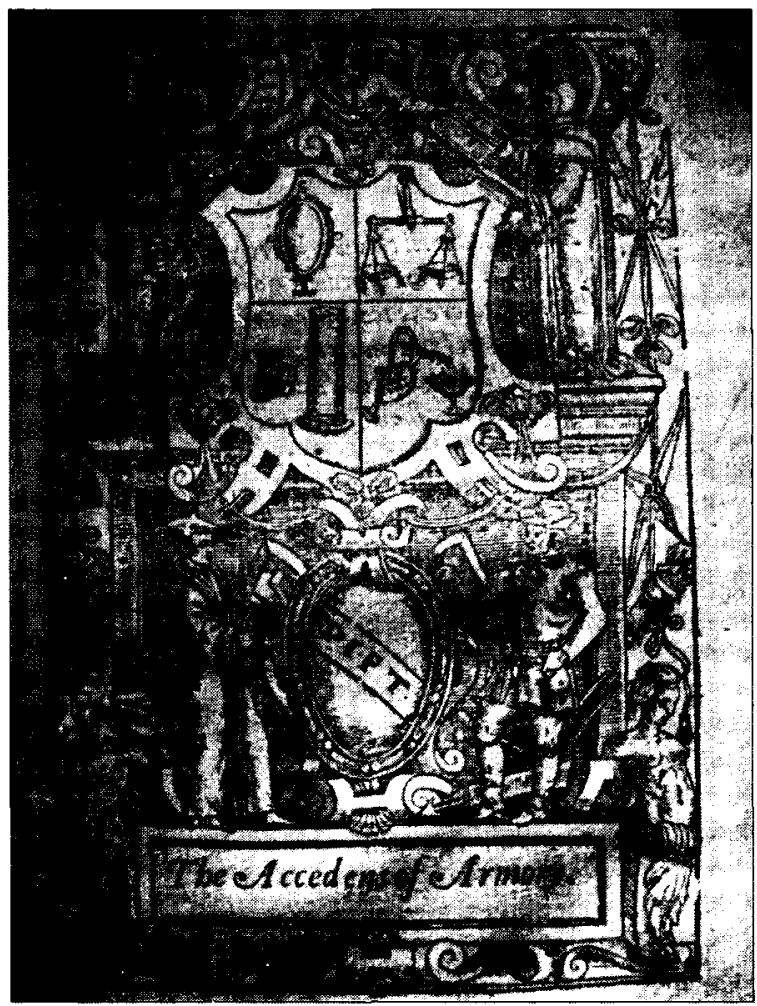

Figure 5.

The Accedens of Armory, Gerard Legh, title page, 1576 , London, Totell.

Permission granted, P. Goodrich.

29. LEGH, supra note 23 , at fol. $135 \mathrm{v}$.

30. Figure 5. 
sword with his right hand to the sovereign. With his left he passes the tablets of the law to a robed and hooded but sighted judge. The left hand of the judge points towards the scales of justice, "the ballaunce of silver in a fielde of blewe." ${ }^{11}$ The visual connotation is clear enough. The judge looks to the laws and reads the book. He does not look to the source of the laws, nor does he blind himself by staring into the heavens. It is to the earthly and tellurian, the leges terrae, that the judge will attend and it is precisely by virtue of sight, through seeing the "dignity of every estate," by marking the differences of rich and poor, that the judge can protect the weak and call the wealthy to perform the duties, the virtues and offices, that their armorial devices portend and portray. Sight is essential to justice and judgment. Causin, in his De Symbolica, a dictionary of hieroglyphs, enigmas, and emblems, is as precise as any: the eyes are the protectors of justice and the guardians of the body-oculos iustitiae servator, et custos corporis. ${ }^{32}$ To give an instance from the very beginning of our period, Erasmus is to the same effect. We can cite the frequent epigrams on the priority of vision over hearing. The Adages of 1500 stipulate clearly that greater faith should be placed in the eyes than in the ears, or in the original oculis magis habenda fides, quam auribus. And we find that theme taken up with proper Christian pride in a number of emblems whose mottos indicate that night and lack of sight are equivalent to ignorance. Everything is invisible in the darkness: res omnes caecus sunt in tenebrae. ${ }^{33}$

Two further images support this initial point. Pierre Coustau, in an emblem titled "on perfunctory judges," presents the image of a judge with

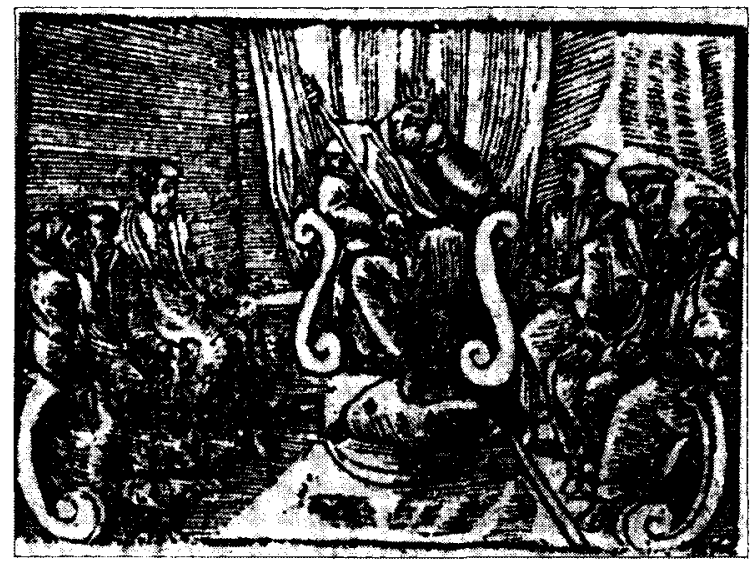

Figure 6.

Emblem from Pegma: cum narrationibus philosophicis, Pierre Coustau, page 209, 1555, Lyon, Matthias Bonhomme.

Reproduced courtesy of the Rare Book Collection, Lillian Goldman Law Library, Yale Law School.

31. Preface to id.

32. Nicolo Causino, De Symbolica Aegyptiorum SaPientia, In QUa Symbola, Parabolae, historiae Selectae, Quae ad OmNem EMblematum, aenigmatum, HiEROGLYPHICORUM COGNITIONEM VIAM PRAESTANT 63 (Cologne, Ioannem Kinckium 1623).

33. Georgette Montenay, EMBlemes, Ou Devises Chrestiennes 36 (Lyon, Macarelle 1571) 
his eyes closed. ${ }^{34}$ The endearingly realistic woodcut is of a judge unsighted by sleep. The immediate reference is precisely to inattention and injustice. Somnus iustitium, the sleep of justice, technically the suspension of justice, is here marked by night and lack of vision, precisely because of the loss of the medium of the image and so the loss of the means of passage between visible and invisible, impression and cause, part and whole. Phantasms and not images occupy the sleeping judge, and these specters of night and dream, with all due respect to Artemidorus and Freud, bear only an indirect relation to diurnal reality. At least they require interpretation of a sort that lawyers are neither wont nor willing to provide. Compare the somnolent judge briefly to an armorial representation of Justice, an introductory image from one of Gerard Legh's contemporaries, John Bossewell, whose Concordes of Armorie offers a somewhat severe-looking Justitia. ${ }^{35}$ Justice here is helmeted

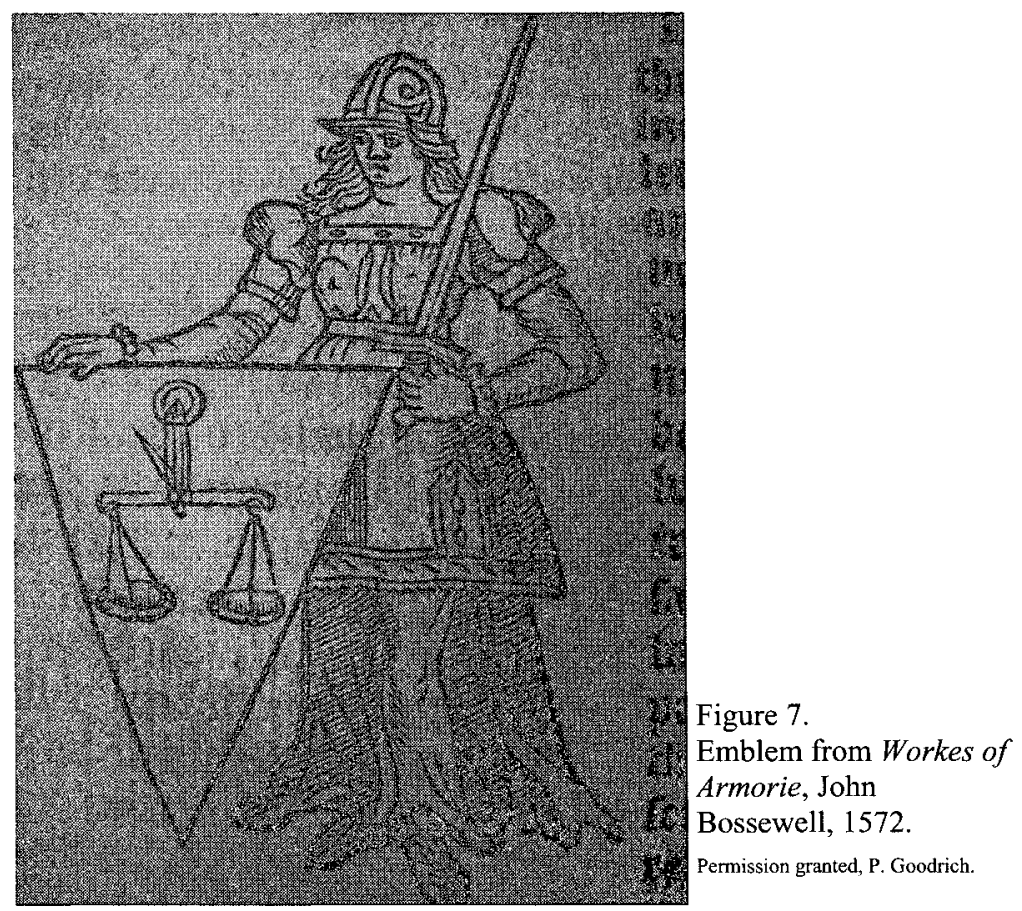

against the threat of injustice, and her sword, unusually, is in her left hand. Her eyes, wide open, look to the right and follow her arm, and particularly her hand, which rests upon an escutcheon with the scales of justice etched upon it. Justice is here put in "dexter" position, in primary

34. Figure 6.

35. Figure 7; see JOHN BOSSEWELL, WORKES OF ARMORIE DEVYDED INTO THREE BOOKES, at fol. 5 r (London, Totell 1572). 
place as the first defense against the violence of misinterpretation by the unlearned and the misrecognition of those not trained to see. Insignia, and here the Queen of virtues, Justitia, are the visible marks of community, of peace through signs, and allow our author to signal, in Latin taken from Isidore of Seville, that arma generaliter omnium rerum instrumenta sunt. ${ }^{36}$ Signs, the codes of identity and norm, are the instruments and means of all communication. They watch out and watch over the order of honor and the proper disposition of things.

Bossewell, not unlike Legh, but with greater abstraction, dictates "that the foundacion of perpetual prayse and renome, is Justice." She stands, as figured in so English a style, with the history of women lawgivers, of Boadicea and, when Bossewell was busy, Elizabeth I, the Virgin Queen, as wide-eyed and watchful protectors of the kingdom. ${ }^{37}$ To them is given the power and the glory, quite explicitly. And on the other side, returning to the Latin, as Agamben has reminded us, is Iustitium, the cessation of justice. $^{38}$ The Roman concept refers to what the English call the dispensation of law, meaning the suspension of legal rule in response to tumult and death. In the more Christian terms of the early moderns, it is emblematic of darkness, breakdown, loss of order, absence of honor, and lack of faith. Hence my suspicion-one that I will now pursue through a genealogy of the image of Justice in relation to the blindfold-that the eyes are the gates of justice and that if they are closed, if Justice can neither see nor be seen, then access is denied.

\section{THE FOOLOSOPHY OF JUSTICE}

The Christian humanist imagery of a sacrosanct Justice and of unsighted lawyers in sixteenth-century Europe operates to identify forms of knowledge from which mortals are excluded, which they must glorify without understanding. The iconic blindfold, which emerges precisely in the course of the establishment of an Anglican common law that will dispense a "knowledge of things both divine and human," functions visually to remind common viewers that the human is separate from the divine, and law from the justice to come. The enigma of the legal emblem thus gains its greatest and most resounding expression in the image of Justice blindfolded. The blindfold is not simply an enigma, a forgotten reference to Homer nodding, to Theban anecdotes, to iustitium. Rather,

36. BOSSEWELL, supra note 35 , at fol. $1 \mathrm{r}$.

37. Id. at fol. $5 \mathrm{v}$. On the history of women lawgivers, see JOHN SELDEN, JANI ANGLORUM FACIES Altera (London, Impens. T.D. 1681) (1610). See also PETER GOODRDICH, OEDIPUS LEX: HISTORY, Psychoanalysis, LAw (1995); Peter Goodrich, John Selden: The Accidental Feminist, in FEMINIST THEORIES OF LAW (Maria Drakapoulou ed., 2012).

38. GIORgIO AGAMBEN, STATE OF EXCEPTION $55 \mathrm{ff}$ (2005). 
the image itself is enigmatic. The blindfold is paradoxical in that it shows but simultaneously censors; it displays without revealing; it is a portrait, an image of a face, but the face is in material part covered. Justice masked is justice unknown. It is this sense of the obvious and at the same time obviously enigmatic that lies at the root of the depiction of the blindfold and can be briefly retraced through the trajectory of its uses.

The blindfold has done the rounds. It is not invented by the Renaissance humanist emblematists. The medieval era knew the blindfold, and there are woodcut images, discussed by Christian-Nils Robert and noted also by Resnik and Curtis, in which condemned prisoners, merchants and lawyers, are depicted blindfolded when being executed. The bandage is there most probably as a sign of punishment, of the condemned, and bears connotations that go back to Oedipus, who tore out his eyes in penance for his crimes. ${ }^{39}$ Many of the early images of Justice show her with empty eye sockets rather than blindfolded, but there is in such cases the obvious visual difficulty that without an explanation for the absence of eyes, the woodcut looks simply as though it was poorly executed or that Justice has had a bad night. It is, in any event, this primary association of the blindfold with censure and incapacity that will be developed here. The most famous instance of such an image is that of Christ mocked, by Michael Wolgemut, to whom Albrecht Dürer was apprenticed, in which a sedentary Christ in a bare room is beaten, spat upon, blindfolded, and bloodied..$^{40}$ The defacement is punitive and salutary, a warning against the worship of idols and the reification of vision. It is this theme of castigation and sacrifice that is picked up in the famous image from Sebastian Brant's early satirical treatise from 1494, Ship of Fools (Stultifera navis). The image is well known and too readily available in this erudite context to require reproduction here. It shows a clown, replete with hat and bells, placing a blindfold over the eyes of a seated figure of Justice, sword in her right hand, scales in her left. The window behind and to her left is small and barred. The window to her right is open and looks onto a scene of civic buildings and a spire. The past is behind her and invisible, and can neither be judged nor balanced, while the future is blank, precluded, and unknowable by dint of the blindfold.

There is a hint of Janus in the image, and I will return to that later, but

39. The comprehensive study is now JUDITH RESNIK \& DENNIS CURTIS, REPRESENTING JUSTICE: INVENTION, CONTROVERSY, AND RIGHTS IN CITY-STATES AND DEMOCRATIC COURTROOMS (2011). See also ROBERT JACOB, IMAGES DE LA JUSTICE (1994); CHRISTIAN-NILS ROBERT, LA JUSTICE DANS SES DÉCORS (2006); CHRISTIAN-NILS ROBERT, LA JUSTICE, VERTU, COURTISANE ET BOURREAU 80-83 (1993).

40. Michael Wolgemut \& workshop, Mocking of Christ, from SKETCHBOOK (ca. 1490) (pen and ink watercolor on paper), discussed and reproduced in JOSEPH KERNER, THE REFORMATION OF THE IMAGE 108 (2004). 
immediately it is the role of the clown that is crucial and somewhat laconically remarked upon in the literature. Brant was a lawyer and sometime-dean of the faculty of law at Basel, and his image is explained in the accompanying and generally vernacular verse-there are several editions - in terms of human folly blinding justice. The text berates those who "ever contend in discord and in strife" and "delight" in going to law over "small trifles ... scantly worth a straw." "41 Yet it hardly needs to be said that, obvious though the image appears to be, it indicates much more than at first appears. Attention should be paid to the clown because it is the human and the civic that errs, that confuses, divagates, and leads astray in much the same manner as those that mocked and tormented and sacrificed Christ. To err is human. Justice and law are constant, immutable, beyond memory, and inviolable. As Coke later put it, in hominis vitium, non professionis: men err but law never. So too for Brant, the clown is not merely a symbol of human frailty and marital discord, it is much more specifically a figure of unlearning and of ignorance. The further and more esoteric reference of the image and symbolism of justice is to degeneration in the study and transmission of the antique law. Justitia represents a timeless and divine rectitude and mercy, force and balance, that is best approximated and learned through the classical texts and the ancient law. Prisca jurisprudentia was to be recovered, polished, passed on. Brant was concerned that the humanistic letters, the Sybilline leaves of antique law were being thrown over in favor of the vernacular and contemporary. This, as Brant and later humanists vocally complained, most notably, to my mind Hotman in his invective Anti-Tribonian, was vandalism, legal barbarism, the work of fools as the image portrays. ${ }^{42}$

Take it a step further. If focus is maintained upon the clown, then the primary indication of the image is that in fact, ironically, perturbingly even, it is the clown, the one who blindfolds, who cannot see. They take the place of those who in Wolgemut's sketch mock Christ. It is those who do the mocking and the wounding that are the real victims, the eternal renegades. This is the inverted world of the carnival, of bacchanal and saturnalia, and augurs ill for the Christian realm. It is Justice whom the artist has rendered invisible, defaced, wounded and lame. If it is the clown, the human who cannot see, then the blindfold is satirical and by inversion marks the invisibility of Justice, her absence. Even though it is a somewhat esoteric illustration of this point, a common Renaissance anecdote, or at least common to humanists and lawyers, concerns

41. See RESNIK \& CURTIS, supra note 39 , at 67-69, and accompanying images.

42. See FrançoIS HOTMAN, ANTI-TRIBONIAN OU DISCOURS D'UN GRAND ET RENOMMÉ JURISCONSULTE dE NOSTRE TEMPS SUR L'ESTUDE DES LOIX (Paris, Perrier 1603) (1567). I cannot resist pointing out that anti-Tribonian is at least phonetically ambiguous, meaning against Tribonian, but also before Tribonian, which is precisely the import and aim of Hotman's argument. 
Accursius, the author of the Glossa ordinaria, the early standard legal treatise. He had a daughter, so the story goes. ${ }^{43}$ And she excelled in law. She was female and beautiful. She wanted to teach law, to be virtuous like her father. For this to be possible it was arranged that she should lecture from behind a screen or, in other versions, while wearing a veil. This way the law students would not be distracted from their studies nor blinded by amorous inclinations. She would simply seem to be a young man. So the story goes, and so it is repeated in our era. The veil protected the spectators, not the speaker. It guarded the vulnerable from the importuning of sight, from the lust of their eyes. And we may legitimately expect that if veils and blindfolds turn up again in this era, then one strong implication of the image will be of a veil that renders the all-too-human viewers unsighted. The lure of the image, the lust that a beautiful face generates, the distraction of the flesh, is here obviated.

Back now to my narrative of juridical uses. When the image of the blindfold returns, in Alciatus's Emblemata of 1531, it appears in the form of a cover over the eyes of "the good prince" as a marker of a humorous kind, accompanied by the image of a council that have their hands amputated. The immediate sense of the image is that it mocks and shames. Politicians should not take bribes, nor should the sovereign be seduced by the appearance of petitioners. Barthelèmy Aneau reproduces the same image of the good prince in the Jurisprudentia. ${ }^{44}$ So too, just to be nationalistic for a moment and concentrate on common law, does Thomas Palmer in the first vernacular English emblem book, Two Hundred Poosees, of $1565 .{ }^{45}$ But that need not detain me here. The point to stress is that the most popular law book ever written, outside of the Corpus Iuris, expressly arrived on the juristic stage genus jocosum, as a satirical, at times obscene work of moralizing precepts aimed to inform, instruct, and amuse those learned in law and the arts. ${ }^{46}$ The story is well enough known. Alciatus composed a collection of adages in the style of Erasmus. These were verbal maxims in Latin with short accompanying explanations and elaborations that were intended for the Saturnalia-

43. My version of the anecdote is taken from a work that defends Mary Queen of Scots, and the regiment of women: JOHN LESLIE, A DEFENCE OF THE HONOUR OF THE RIGHT HIGHE, MIGHTYE AND NOBle Princess MARIE QUEENE OF SCOTLANDE AND DOWAgER of France, at fol. 193r (London, Dicaeophile 1569).

44. Figure 8.

45. The Emblems of Thomas Palmer: Two Hundred PoOSEes 25 (John Manning ed., AMS Press 1988) (ca. 1565) ("[T]hese images well dighte . . . The Kinge is blinde what meanethe this? / forsothe with one affecte / He heres the cawse, sees not the man / nor hathe to hym respecte.").

46. The classic study is PAUL VIARD, ANDRÉ ALCIAT, 1492-1550 (1926). For a recent study, see Pierre Laurens, L'invention de l'emblème par André Alciat et le modèle épigraphique, in 149 ACADÉMIE DES INSCRIPTIONS ET BELLES-LETTRES 883 (2005). I should add for the sake of future rankings that the Institutes of Gaius, still in print, should also probably stand proud in terms of longevity and popularity. 
festivis horis - and for which he coined the title Emblems. He sent these to his publisher, the Augsburg printer Heinrich Steyner who, without the author's permission, added woodcut images to the epigrams and their explanations. The rest is, in one sense, history.

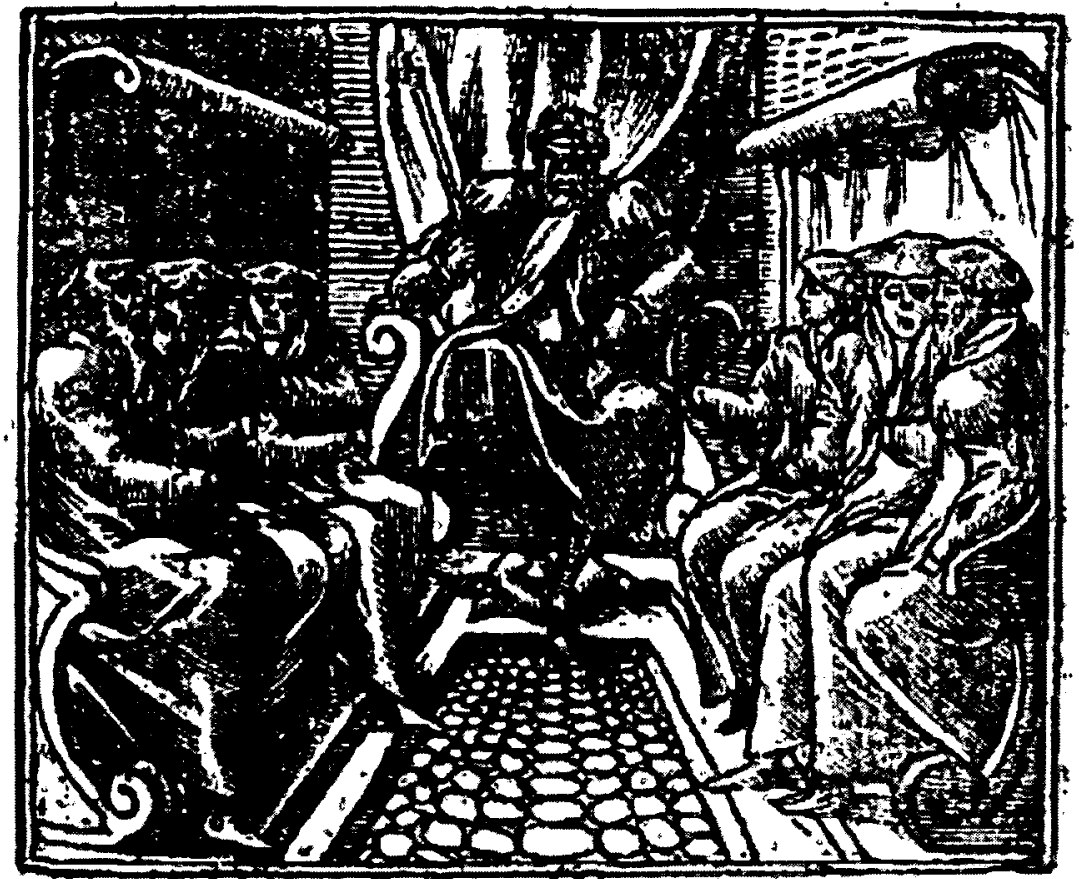

Figure 8. Emblem from Jurisprudentia, Barthélemy Aneau, page 34, 1554, Lyon, Bonhomme.

Reproduced courtesy of the Bibliotheque nationale de France.

The prince who wears a blindfold, and to an even greater extent the counselors who have their hands amputated, are fools, a salutary lesson and moral depiction of those condemned for crimes against the common good. That theme usually recurs in the later editions of Alciatus, as in the first vernacular emblem books, in relation to the blindfolded Cupid, indicative of the folly of love. Also common are blindfolds on Fortuna and less frequently on those whom Death, a dark skeletal figure, will take away. Fortuna is an intermediate example, and we find her naked, blindfolded, and masked a second time by an expansive sail in the first vernacular emblem book, Perrière's Theatre. This depiction is critical and parodic. It is the blind who follow Fortune's lead. And when the blind are led by the blind only disaster and darkness can follow. ${ }^{47}$ An even more explicit instance can be taken, for reasons of diversity, from the second

47. PERRIĖRE, supra note 5, at 20; see also COMBE, supra note 5, at 20. 
vernacular emblem book, Corrozet's Hecatomographie of $1540 .{ }^{48}$ Corrozet is, if anything, more direct and virulent. Fortune lies and on account of her mendacity is thrust out of the heavens. In the emblem she

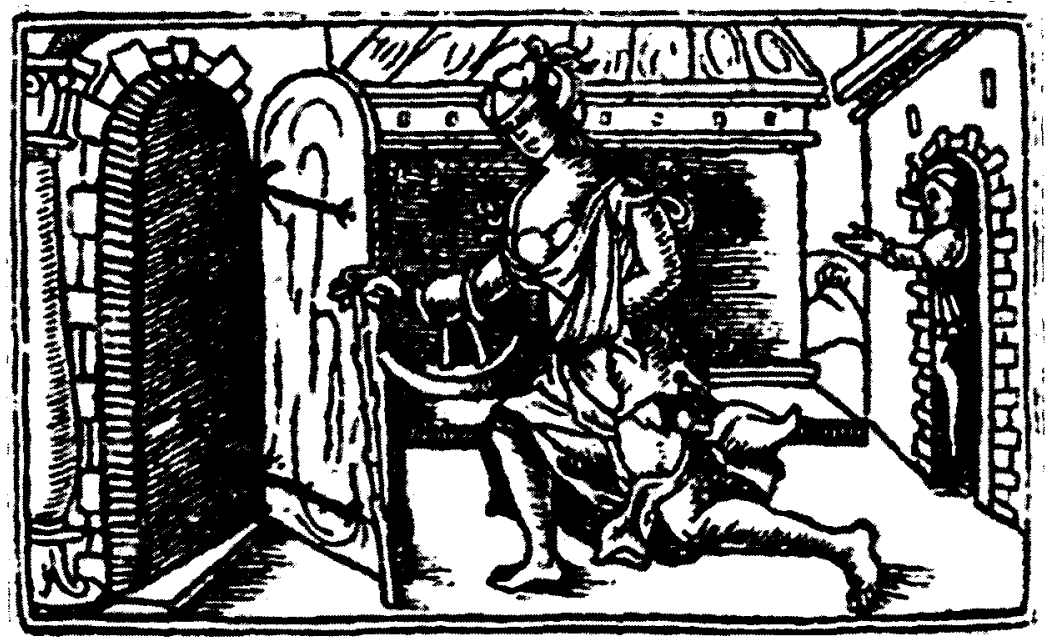

Figure 9. Emblem from Hecatomographie, Gilles Corrozet.

Reproduced courtesy of the University of Glasgow Library, Special Collections.

is depicted as being thrown out of the human house as well. She should not be obeyed on earth, at sea, or in the sky because she importunes, is inconstant, and leads astray. She is shown blindfolded, one arm in a sling, a weight on the other, as she is hurried out the door and into darkness. The message is simple: be gone. The future cannot be known, and the winds of chance, Fortuna, is neither guide nor friend in its denouements.

One other instance of the blindfold in a satirical setting can also be taken from Perrière's Theatre. It is highly indicative and picks up on the less obvious meaning of the blindfold, namely the unknowable quality of the future and, in Christian terms, the afterlife. Emblem 93 is of marriage. ${ }^{49}$ Under a proscenium style of arch, in the theater of the theological and social, a priest in cassock and frock stands framed by what appears to be a chancel. The husband is portrayed blindfolded, with his hands also bound. Around his neck is a chain by which he is further ensnared by the bride around whose waist the chain is locked. This, in the Christian tradition, is a literal image of wedlock, of voluntary servitude, the prison we choose, the golden chains of marriage. That said, the "happy couple" look about as unhappy, as downcast and depressed, as could possibly be imagined. There is no joy in this marriage, and the reason for this is not entirely obvious. The immediate ground given for

48. Figure 9; see Gilles Corrozet, HeCATOMOGRAPHIE (Paris, Janot 1540).

49. Figure 10. 
the blindfold and chains is that a wife should be chosen for virtue and not for looks. If she is beautiful, then others "will be fingring of the chinke" and will cause unhappiness and destruction by having their hand in the pie, to borrow from Combe's rather graphic version of this emblem. ${ }^{50}$

The doctrinal meaning of the image follows from the warning given. In loving virtue, we must love not the body, not the woman, but the faith, the Church, Christ. The marriage is ultimately to God and to the future, and the body, here the woman, is simply a vehicle to everlasting life. As with the blindfold on Fortuna, the bridegroom's blindfold signifies not only a

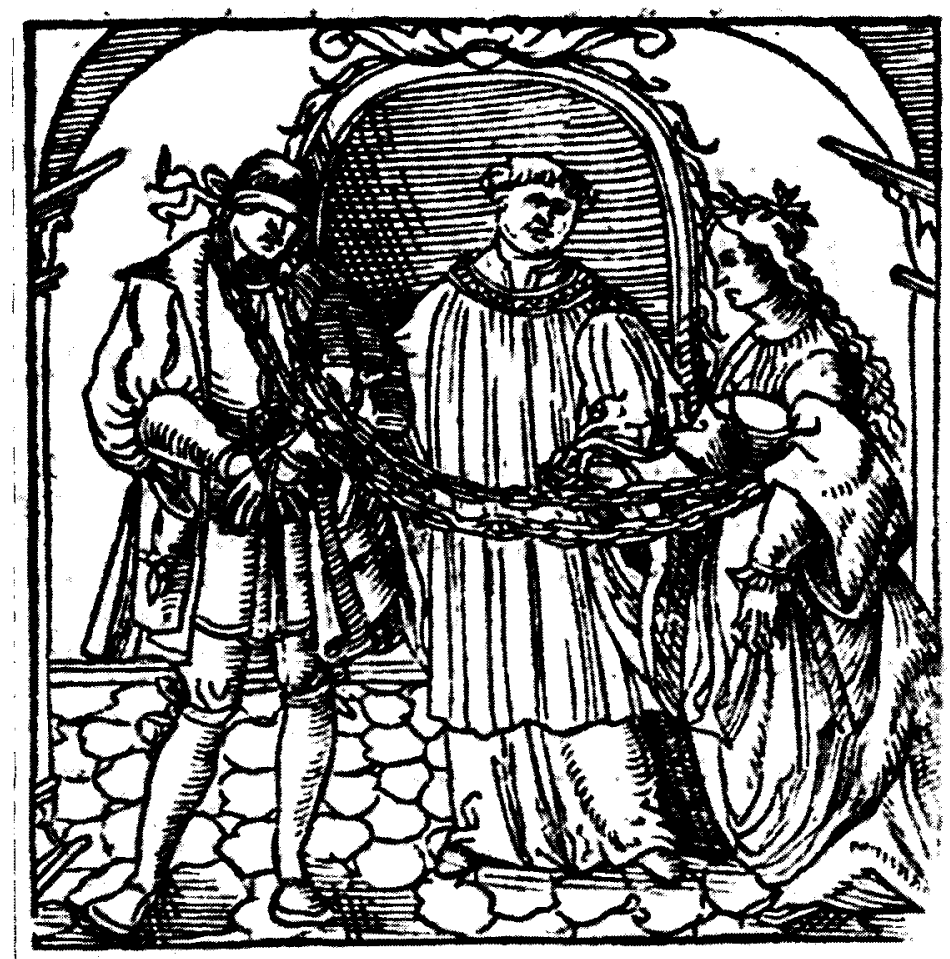

Figure 10.

Emblem from

Theatre des

Bons Engines,

Guillaume de

la Perrière, page 93, 1540.

Reproduced courtesy of the University of Glasgow Library,

blindness to earthly things but also the unknowable character of the future. This theme is important not only to the destiny of faith but also to the imagery of justice. Brant's Justice is depicted very clearly as being blindfolded and so blinded in relation both to the past and future, while to her side an open window at least provides potential access to the present and the civic. These could be seen, but they are not. Yet her defaced visage is not turned to the actual; it faces the front, the future, in a play upon temporality and faith that we find taken up in several emblems of Janus. The face that looks forward looks to the future, and this is often 
depicted by a key, the clavis regni or key to the kingdom to come. ${ }^{51}$ The blindfold signifies perhaps the limitation of vision, and we find this most expressly in Damhoudere's famous emblem of Justice with two faces in the 1572 French edition of Practique Iudiciare es causes civiles. ${ }^{52}$ It is the future that worldly Justice cannot see, and the blindfold here makes that fact visible and evident. It is a point that I can reinforce by considering a rather extraordinary figure of a three-headed satyr at the beginning of The Foolosophy. ${ }^{53}$

The image of the satyr is accompanied by an honorific dedicatory poem to the author, which explains that our lawyer Perrière is the most learned of doctors. It continues to observe that the past can be recovered so as to

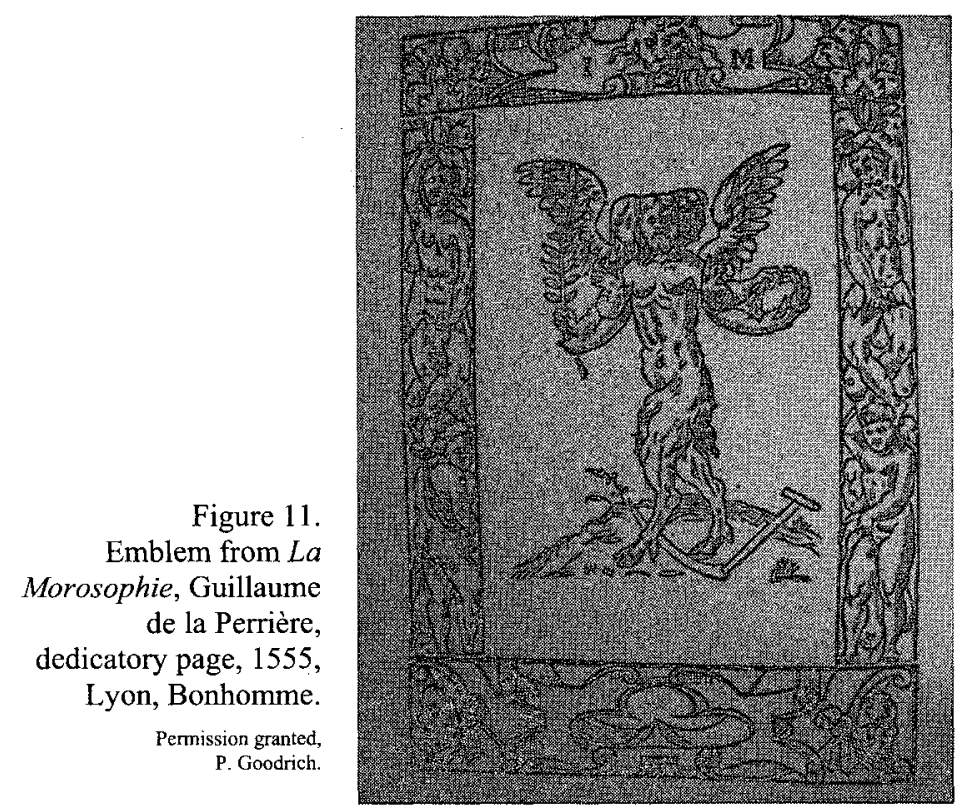

augment your glory in the present, but it is in the future that you will be crowned. The image, however, hints at a slightly different story. It would be easy to miss, so I will point it out. The winged satyr has a bearded and Socratic face turned to the past. It is in full relief and clearly depicted. The face looking out to the present is only half in the light, and half in shadow, in tenebras. The face that looks to the future and to the crown of laurels is wholly in shadow, ill-defined, and dark. The implication again is that the future is invisible and, whether blindfolded or not, eyes are useless if the

51. See Gabriel Rollenhagen, NuCleus Emblematorum SElectissimorum, at II.4 (Cologne, Crispiani 1611); GEORgE WiTHER, A COLleCtion OF EMBlemES ANCIENT AND MODERENE 138 (London, Allot 1635).

52. Joost de Damhoudere, Practique iudiciare Es Causes Civiles tres Utile Et Necessaire A Tous Tous Baillifs, Prevosts, Chastelains (Anvers, Bellere 1572).

53. Figure 11. 
future is the object of vision. It is all dark, all night. And, as Saint Augustine fondly relays, one sees through faith and by means of oculi animi - that is, by spiritual vision-all of that kingdom that is not and has no being, that is intima non extima, as the lawyers were wont to say.

For our immediate purposes, the intimation of the latter emblem is important to the reconstruction of the image of Justice sighted and lawyers blindfolded that Aneau will later borrow from Perrière's Foolosophy ${ }^{54}$ First note the obvious title, Morosophie, after Erasmus and his Encomiae moriae of 1509. It is part of a now-venerable tradition in which human frailty is exposed and explained. The image is foolosophical

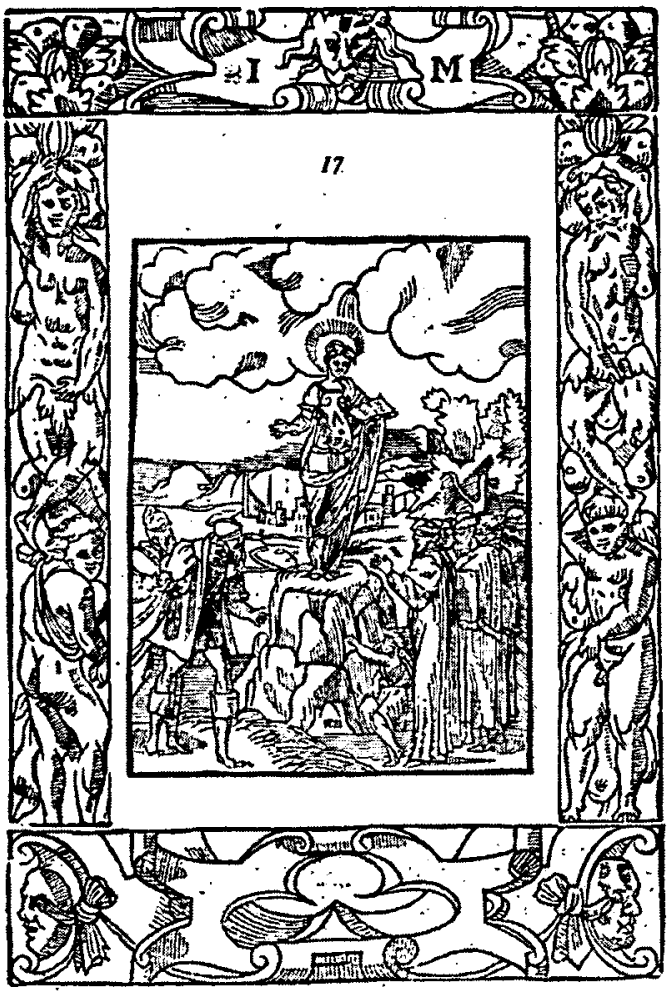

Figure 12.

Emblem from $L a$ Morosophie, Guillaume de la Perrière, page 17, 1555, Lyon, Bonhomme.

Reproduced courtesy of the University of Glasgow Library, Special Collections.

and should be interpreted, at least here, in that vein. It shows Justitia fully sighted and declaiming from the book of the laws to the muddled, blindfolded assembly of lawyers. This suggests, foolosophically, that lawyers do not see very much and are indeed impeded in their efforts by their inability, their failure to read the law and to apply it to the future. The blindfold, which incapacity they share in this image with Cupid, marks their cupidity, to be sure, but also their confusion, limitation, and simple lack of vision. This feature of incapacity and impossibility is also 
remarked on in an earlier satirical dialogue, Battista Fiera's On Painting Justice, published in 1515, which has been most usefully recuperated and discussed in Representing Justice. For Fiera it is all very clear and easily stated: nothing is clear. Indeed, non pingi posse Iusticiam-Justice cannot be painted. ${ }^{55}$ Justice is beyond human comprehension, she belongs to another sphere and the blindfold signals to keep out, noli sapere altum, not to blind yourself, not to burn your wings, not to wound or mutilate a fragile mortality by trying to know beyond your mortal station. Justitia's blindfold signifies a double message. On the one hand, it shows clearly and painfully the limits of lawyers, their earthly incapacities, their downcast bent. At the same time, and somewhat paradoxically, it also indicates more esoterically a classical mythological order and the accompanying ascetic rites and occult ceremonies in which they participate. To understand the theatre of justice and truth, and the circulation of imagery in the sixteenth-century common-law tradition, it is necessary to appreciate the political theology of sovereign rule into which the lawyer was arduously apprenticed. The lawyer had to learn, to see and understand, the divinity immanent in human customs and dimly glimpsed in the practice of law.

\section{ANEAU'S JURISPRUDENTIA}

What does the borrowed image, the found emblem, that Aneau uses in the Jurisprudentia mean? Should we even inquire? Do we need to know? One could take the advice of Robert Burton and shore up Fiera's conclusion. The melancholic Burton opines, "when you see the cover, why ask about the thing hidden? It was therefore covered, because he should not know what was in it. Seek not after that which is hid . . ."56 Keep out is the message, and Democritus Junior believes, it seems, that the instruction is sound and to be observed. But of course Burton never followed his own advice. He revealed, for example, that he was the author of the work attributed ironically on the title page to Democritus Junior. So he lifted the cover and took off the mask. Using Aneau's textual emblem, we will endeavor to do the same.

55. Battista Fiera, De Justicia Pigenda 23 (London, Lion \& Unicorn Press 1957) (1515).

56. DEMOCRITUS JUNIOR, THE ANATOMY OF MELANCHOLY 3 (Oxford, Cripps 1628). 


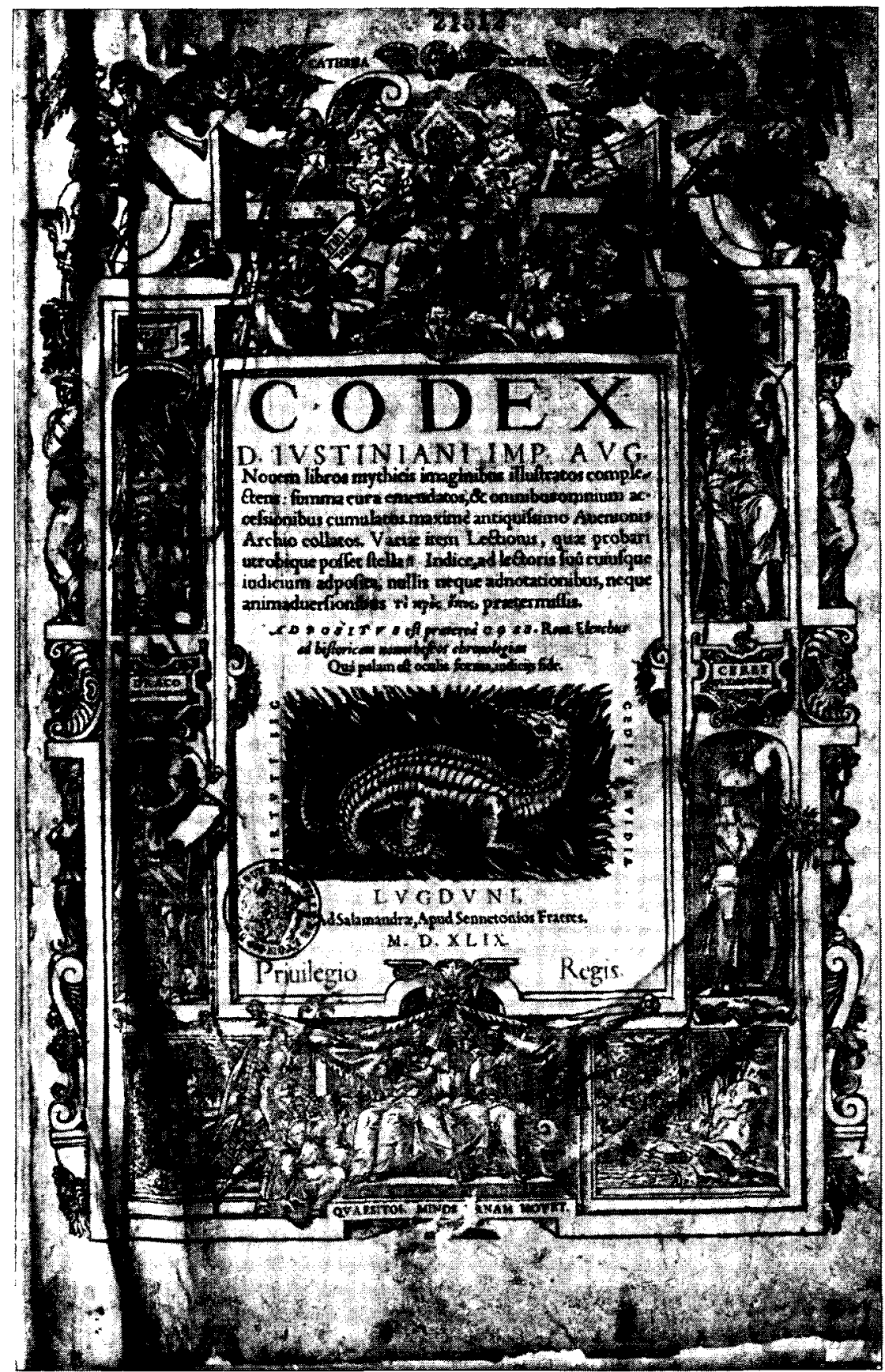

Figure 13. Title page to Codex D. Iustiniani Imp. Aug., in Justinian I, Corpus Juris Civilis, 1548, Lyon, Senneton Frères.

Source: Bibliothèque municipale de Lyon, 21511. Crédit photographique Bibliothèque municipale de Lyon, Didicr Nicole. 
Aneau can even be our guide. In Picta poesis, published two years before Jurisprudentia, he elaborates elliptically upon his method. At the conclusion of the preface to the work he reports, "I have at times been forced to follow my own conjectures and divinations and rather than adapting the images to the words I have sought the words best suited to the images." ${ }^{57}$ Aneau is an emblematist to the core, one could say. What matters is what we see, the images of the good, the clear-sightedness of justice. An earlier and even more esoteric reference, brilliantly elaborated upon by Hayaert, can also lend support. Aneau prepared the images for the Senneton brothers' edition of the Corpus Iuris Civilis, published in Lyon between 1548 and $1550 . .^{58}$ The frontispiece to the Codex bears a striking image and an illuminating motto. ${ }^{59}$ There is too much on which to comment, but consider the statement: Quà pallam est oculis forma, iudicjis fide. It is hardly Latin that Cicero would recognize but means in effect that "faithful judgment occurs when law is put clearly before the eyes." Evidence, if ever there was, that law and vision, the ability to see the law and to see the facts of the matter in vivo are essential to justice. ${ }^{60}$

It is the visibility of law, the frontal representation of the invisible order and hierarchy, that the title page so clearly illustrates. At the top, angels trumpet and surround Homer, whose chains bind Moses and Solon and then pass by their hands, via Dracon and Ceres, to a judge, who chooses jurors by lot. The lower center image-the nombril point-is of the Senneton salamander and represents the fire of virtue that will drive evil away. In the next image, as if immediately to figure the titular image, we have an emblem of "the most sacred prince Justinian," who has collected the kernel of the antique law and now passes it on to the people. ${ }^{61}$ Justinian is crowned and robed with a rod of office in his right hand, while with his left he points to scribes, notaries, and lawyers, who are inscribing his laws in a great book. Justinian is sighted well enough and looks down, while the lawyers avert their eyes from the sovereign so as to capture collectively and scripturally what Justinian dictates from his throne.

57. Barthelémy ANEAu, Picta POESIS UT PICTURA POESIS ERIT 6 (Lyon, Bonhomme 1552).

58. CORPUS IURIS CIVILIS (Lyon, Senneton 1548-1550). The bibliographical details are discussed at length in HAYAERT, supra note 3, at ch. 6. It is to her that I owe both my thanks and the digital copies of emblems from that work.

59. Figure 13.

60. Another example, which I will not pursue here, can be taken from a later emblem book. FRANCIS QUARLES, EMBLEMS DIVINE AND MORAL TOGETHER WITH HIEROGLYPHICS OF THE LIFE OF MAN (Bristol, Landsdown 1808) (1630) shows justice, blindfolded, bringing a sinner before a cherubic Christ. Christ is writing and looks up to see and dismiss justice for her rigidity and lack of clemency. She cannot see, whereas Christ "beholds" the sinner: "I spy my Father's image in the prisoner's eye." Id. at 119.

61. Figure 14. 

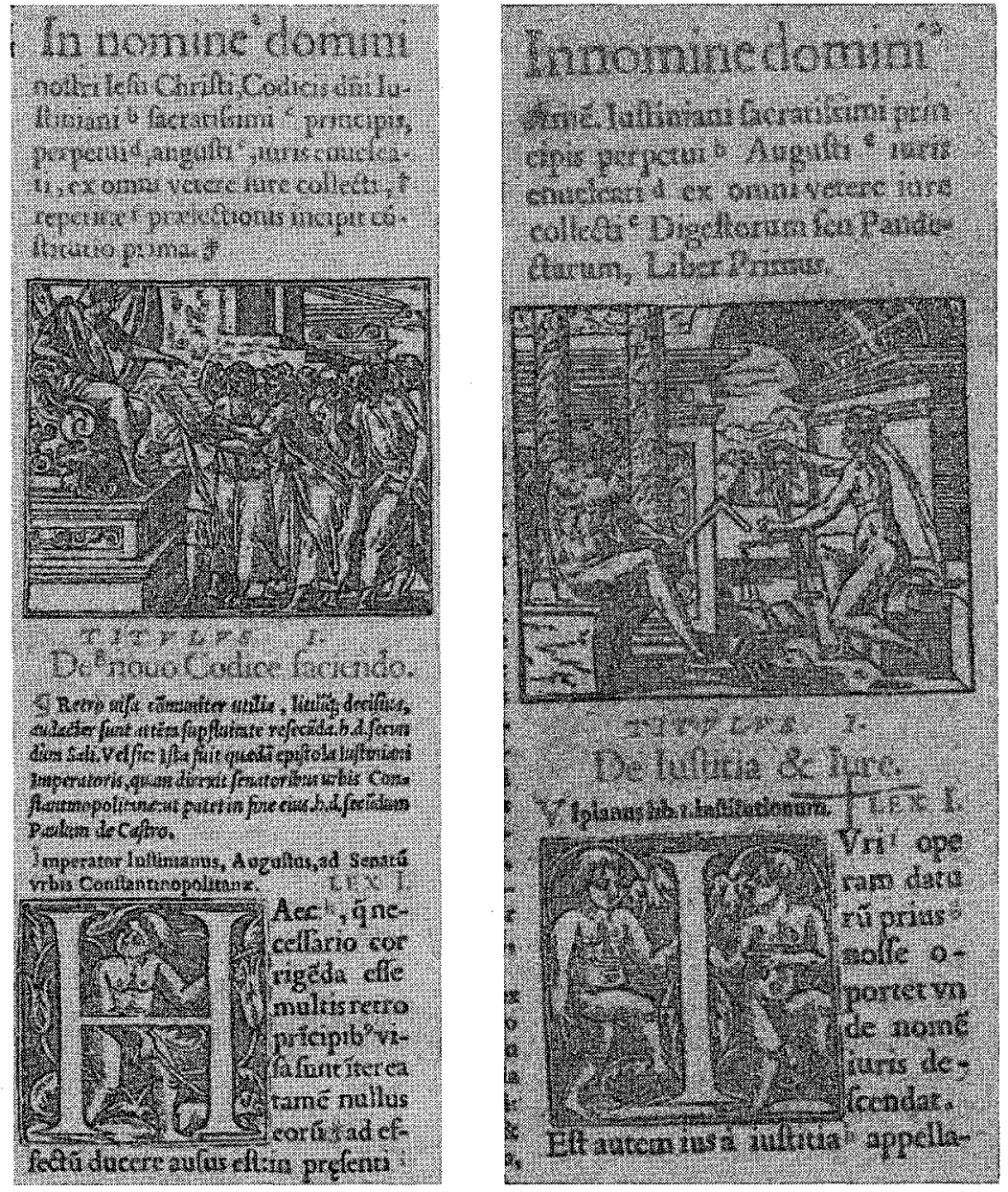

Figure 14 (left). Emblem from Justinian I, Corpus Juris Civilis, Digestum, col. 11. Figure 15 (right). Emblem from Justinian I, Corpus Juris Civilis, Codex D. Iustiniani Imp. Aug., tit. 1 col. 1. 1548, Lyon, Senneton Frères.

Source: Bibliothèque municipale de Lyon, 21511. Crédit photographique Bibliothèque municipale de Lyon, Didier Nicole.

The name Justinian comes of course from Jus, law, which term itself derives from Justitia, or so we are informed in the first sentences of the first book of the Digest. Ponder that a moment, and then consider the accompanying emblem in the Senneton Corpus, an image of Justice sitting down with Law. ${ }^{62}$ Law sits naked on a pedestal with the instruments of cartography, compass, and square in his hands, at his feet.

62. Figure 15 . 
The image of law is of strict judgment, of geometric rule, of line and text inexorably leading to determination whatever the consequences-pereat mundus one could say. Opposite law, seated slightly higher, her face turned upwards in contrast to law's downcast eyes, is Justitia. She too is naked, Edenic, or angelic, as one wishes, and has a band, a "skarfe," around her head while she proffers to law the sword and the scales of justice. This is her gift. A sighted divinity teaching from on high, modeling virtue in visible form to the benefit of a rather constrained and constricting figure of legality.

The image from the Senneton edition could as well have been used in the introduction to Aneau's Jurisprudentia, which was in all probability its source. Turning then, now, a long time later, because these images are not easy to recuperate at such a great temporal, geographical, and doctrinal distance, to the immediate context of his Justitia, the initial,

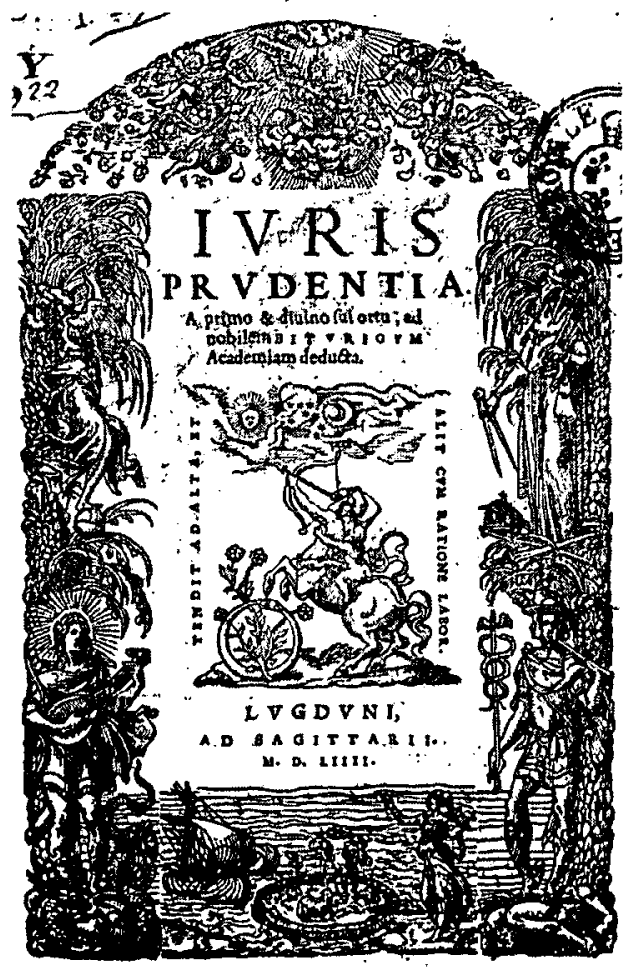

Figure 16. Title page to Jurisprudentia, Barthélemy Aneau, 1554, Lyon, Bonhomme.

Reproduced courtesy of the Bibliotheque nationale de France. obvious-though-forgotten point, is to look at the progression of images in Jurisprudentia. Our opening figure, Justitia on her pedestal above the blind attorneys, does not appear ex nihilo but rather in the context and combination of the other images in the text, the accompanying trajectory of emblems, of icunculae, as they were once termed. ${ }^{63}$ The jurists follow their own poetic and aesthetic criteria, their own spectral laws. To begin to insert this image in its proper context we should start with the title page, its emblem and other images. Here jurisprudence is presented as upon a stage. ${ }^{64}$ The arch above the title shows Justitia in the clouds, with both sword and scales in her left hand. In her right she holds

63. The immediate source for this term is THOMAS PHILIPOT, A BRIEF HistoriCAL Discourse OF THE ORIGINAL AND GROWTH OF HEARLDRY DEMONSTRATING UPON WHAT RATIONAL FOUNDATIONS, THAT NOBLE SCIENCE IS ESTABLISHED 7 (London, Tyler \& Holt 1672).

64. Figure 16. 
Nomos, law, while a heavenly hand emerges from an arm-like cloud to hold Nomos from above. To the right, angels cavort, eyes open, wings spread. To the left, angels descend to the outstretched arms of the angel of knowledge (metaphysic in the later tradition), who stands upon a globe, and then below to harmony, who stands upon a slain dragon. To the right, the angels of justice descend to the figure of Pythagoras with his measures and then to Mercury, while at the bottom of the frontispiece the human stage is represented by a small island, circled by a serpent biting its tail and so forming a ring on which a lamb, the sign of Christianity, stands.

That is the frame, the order of things, of signs and meanings, of power and law, force and justice made visible and present. ${ }^{65}$ In the center is the title page emblem, a version of Astrologus and of the maxim tendit ad alta, which warns against human hubris and argues that Nomos should rule from above while the subjects of law look up from below but ought not to try to climb too high. Here very clearly, and not solely in the subtitle (a primo et divino sui ortu), the angels rule above while our crowned and winged Nomos passes on the trusts of law by means of images. Aneau signs the work visually with the emblem of his name, a ring (Annulum) with flowers, flores legum, growing through it. The image of the name, not the name itself, but rather its visible figure, its symbol, something more, its meaning and possibility, which the Christians of the period might term verba-nomina-visibilia, the visible word, the sacrament.

The next image of invocation or prayer is even more direct and disconcerting to modern eyes. A subject, the burden of the human on his back, is on his knees, supine, abased, genuflecting, arms outstretched,

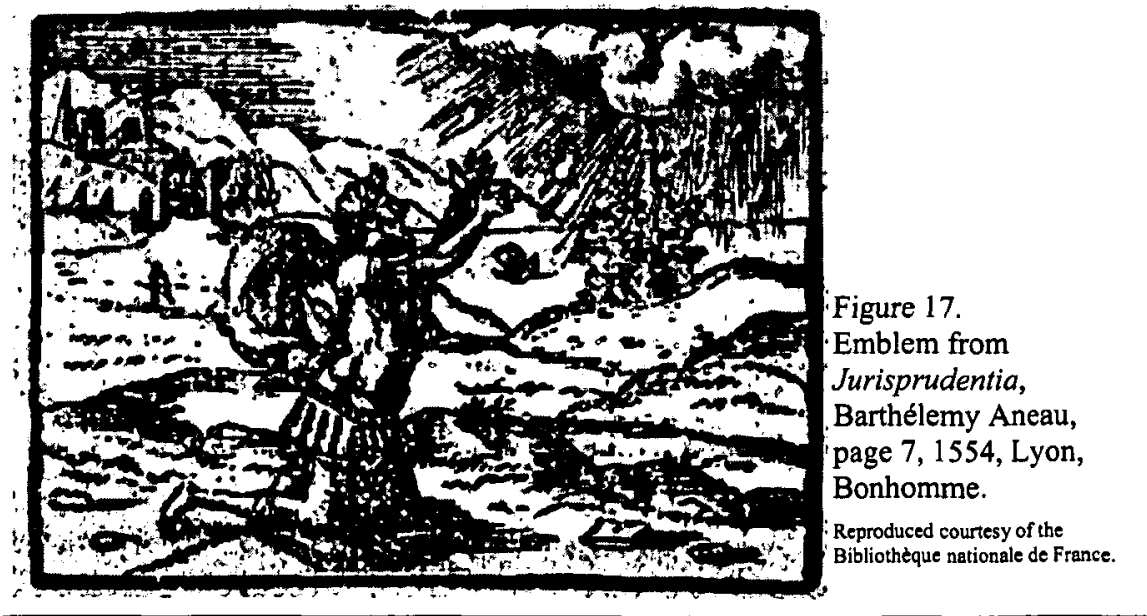

65. MARC FUMAROLLI, L'ÉCOLE DU SILENCE: LE SENTIMENT DES IMAGES AU XVII ${ }^{\mathrm{E}}$ SIÉCLE 325 (1994). 'Le seuil des livres' provides a helpful discussion of the connotations and doctrinal implications of these opening images. 
invoking divine aid and succor. ${ }^{66}$ The pleading subject raises his face to the light that emanates from the clouds, from above, from the beyond. If the image of invocation were not evident enough, the next image of paternity, both divine and human, shows a child pointing at an old man and asking whence he, the child, came. ${ }^{67}$ The astronomer responds that the old man sitting under a tree is the father of the child's body and that the angel of justice, winged and armed with sword and scales, is the maker of his soul. The divine Justitia is here both airborne and sighted, a mark of visible origin and of pending authority. It is the supreme impiety (summa impietas) to refuse to recognize your father and not to reverence the divine.

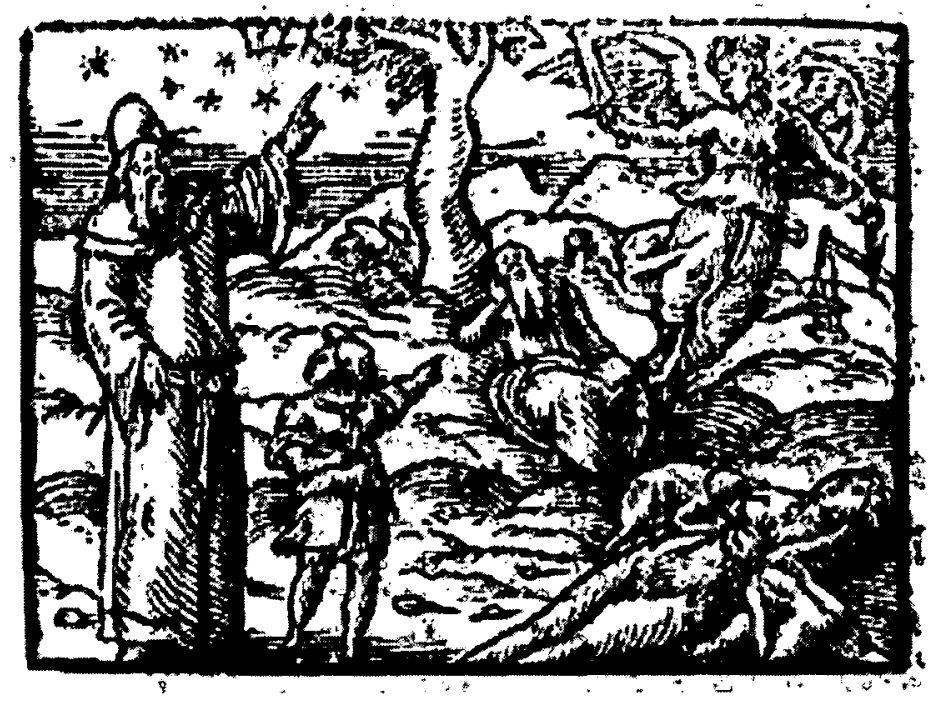

Figure 18. Emblem from Jurisprudentia, Barthélemy Aneau, page 8, 1554, Lyon, Bonhomme.

Reproduced courtesy of the Bibliotheque aationale de France.

The child is father to the man, and in the next image of devotion and civic virtue, we see in the background a temple and praying figures and in the foreground prostrate humans behind two large figures flinging rocks. Danger gives rise to belief, and experience teaches reason. ${ }^{68}$ The figures in the foreground are Deucalion and Pyrrha, two survivors of a great flood, according to Greek mythology. Their statuary presence here signifies that only belief and the lessons of experience, of adversity

66. Figure 17.

67. Figure 18.

68. Figure 19. 
overcome, lead to eloquence, virtue, justice, and law. Blindfolded, heads covered, their mantles billowing behind them, they are statuary emblems that warn against chance and folly in favor of worship and civic virtue. The statues are shown holding stones, which they throw behind them to form children to re-propagate humanity after the deluge. There are various versions of the myth in Ovid and pseudo-Apollodorus, but here it is enough to point to the covering of the head as the mark of human incapacity, of gratitude and praise for all that cannot be seen and must be obeyed according to the logic of myth. It is indeed poetry, the mythical narratives and theatrical performances of Seers, that allow us, according to Aneau in his next disquisition, to understand and interpret the gods.

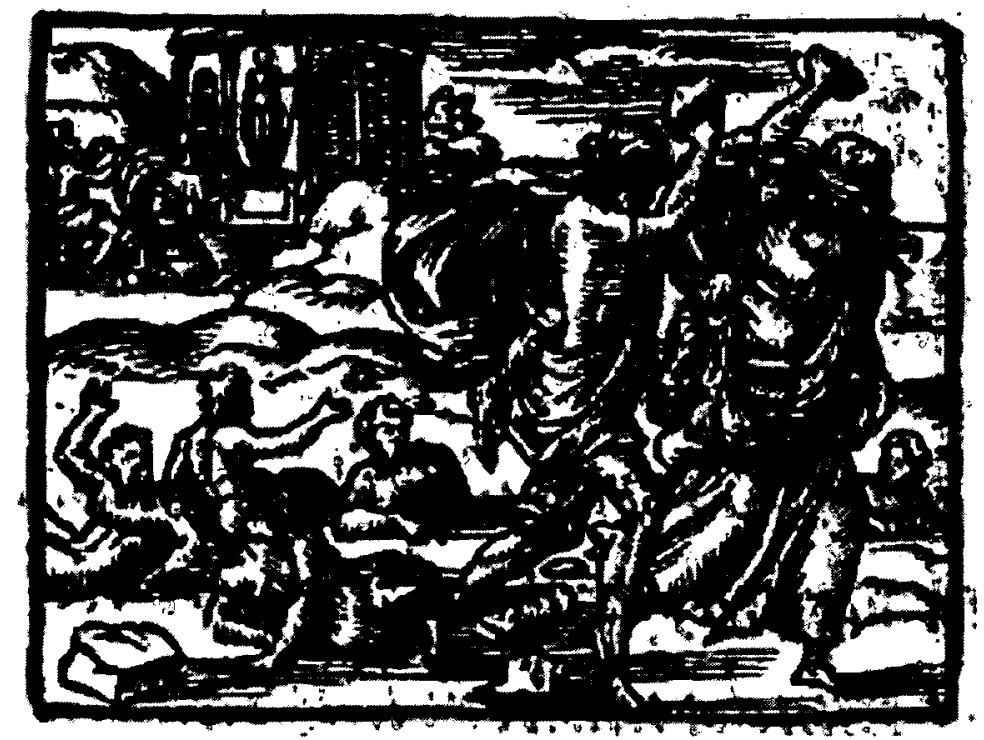

Figure 19. Emblem from Jurisprudentia by Barthélemy Aneau, page 9, 1554, Lyon, Bonhomme, 1554.

Reproduced courtesy of the Bibliothèque nationale de France.

This leads him to the homines sacer who will give and interpret the laws, who will bring community and agreement through wisdom and strong rule. Fiction, the moralizing stories of the ancients, the narratives of myth, ground knowledge and law in antiquity, eloquence, and art. Such then is the image relay that subtends and traverses our specific emblem of Justice.

Proceeding ad apparentiam, according to the succession of images rather than their reduction to textual and literal explanations, we are in a position to properly view the next picture in the progression of images. This shows Justitia sighted and the lawyers blindfolded. What now of this Justitia? Begin by treating the image as following directly from the 
previous depictions of the angelological, acclamatory, and mythical. She is no longer winged and flying but nonetheless, even though now on the earth and amongst men, she is on a pedestal, above and looking down. Justitia's head, replete with halo, is held in nubibus, in the clouds. Two markers of the divine already light her place and performance, two of what Agamben, in his study of oeconomy, The Power and the Glory, terms the crescendo of optical metaphors that accompany the biblical description of the divine. And then a third optical reference. Jusititia is sighted and has the book of laws in her left hand, while her right hand is outstretched, signifying power, eloquence, and donation. ${ }^{69}$ She is giving the law, and the law is divine, comes from above, from pater noster, from the great elevator and, in the humanist vernacular, Our Father. Contrary to the convention in statuary and other depictions of Justitia, she is sighted and declaims the law, while it is the lawyers who are blindfolded and who look ahead or down as Cupid, also blindfolded, walks among them.

The lawyers cannot see and indeed hardly appear to be listening. They are rather stumbling around, oblivious to the light, blind and all too human. One interpretation, Aneau's suggestion in his accompanying text, is straightforwardly humanistic. He aims to restore prisca jurisprudentia, the full, classical text, unadulterated by Tribonian's adulterations, interpolations, excisions and other barbarisms. To take out the so-called emblemata Triboniani, the false emendations of the compilers of the Corpus Juris, required extreme erudition inherited from not only the most ancient expositors (antiquissimi expositores) but also the most recent angelic legal luminaries of his own era, the Bartolists (succedentes maxime insignes). In this aspect the blindfold on the lawyers is a mark of asceticism and learning, the visible representation of the Pythagorean doctrine of a lengthy and arduous apprenticeship to knowledge, of many years spent fasting and studying, according to Iamblichus, before the subject was worthy to join the ranks of the learned. The blindfold marked deprivation, self-abnegation, and purification.

Why the deprivation and ascetic rites? For Aneau, this training was both to prepare the lawyer-interpreter for a better world and its higher law and to link the subject to the mythological roots of prisca jurisprudentia. Chief amongst such myths is that nomos is immanent and, properly speaking, partially visible in practices and patterns, customs and uses of the quotidian world. The text, in its purest, most practical, and longestretained form is not written but rather is inscribed in the heart because, according to another maxim, omnia scrinia habet in pectore sua. Thus

69. The outstretched right arm signifies power-a long hand of authority-as well as protection. See John Bulwer, Chirologia: OR, The Natural Language of the HaNd (London, Hatper 1644). 
Lycurgus of Sparta, also a Greek, forbade the law from being written because writing would lead only to forgetfulness, whereas law should be embodied, internalized, emblematized, and thrown within. It should be written on the heart, lived, breathed, imbibed, ingested, and even sneezed according to the English civilian William Fulbeck. Hence the first point, which comes as something of a surprise: the blindfold signifies the unwritten law, ius non scriptum, the English lawyer's déformation professionelle, except that here, as almost everywhere else, the English legal condition is simply that of having forgotten their Roman sources.

If you cannot see it, you have to look elsewhere, to use the inner eye, the eye of the spirit, and to search for law non extima sed intima. And from the picture of Justitia declaring the law, just as her temporal namesake, Justinian, declares it in the opening image of the Senneton Codex, the law should first be apprehended, listened for, heard as it rises through anamnesis from within. Listen but do not look is also a prohibition and should be understood as such. Not to be able to see is a human adversity, a disability, at the least a suspension of sight so as to allow for the apprehension of the sub-auditory murmurings of mythos, of custom and use as they embody nature and law. While this may have a moralizing message, it is really no more than a species of homage, of passing under the yoke, of recognizing that we are below and that lawgivers and Justitia are above and beyond.

\section{CONCLUSION}

Last words. Final images. The blindfold on Aneau's lawyers represents an injunction not to look, not to stare upon the earthly realm, let alone the divinity on high until they are ready, trained, and able. It is an ascetic and salutary indication of the limitations of the lawyer and of the subservience that they must display. It is not Justitia who is blind. As adumbrated, and irrefragably, even if there was a blindfold on Justitia it would not signify that she could not see but rather that she could not be seen. Aneau thus offers the image of the lawyers blindfolded to make more apparent and somewhat more comic and engaging, somewhat more foolosophical and accessible, the theological message of the image, namely that only those who have joined the order of the angels, only the holy lawyers, the superillustrious, the spectacularly dignified, the iuris periti, or in reality the legal doctors of Bourges from whom Aneau hoped to obtain a university appointment, can engage with the solemn dictates and divine decrees of the juridical. 
And where does this leave us with Justitia and her blindfold? Return for a moment to Pierre Coustau's Pegma of 1555 . The title of the work, a thoroughly legal intervention, refers to a theatrical machinery that raises and lowers actors and props onto and off the stage. His work begins with three images, a triunity of emblems of Justice. I offered initially, to set the stage, the image of Justitia against corrupt judges, according to Nigidus. She sits on a cloud, a sword in her right hand, cleaving a path between the stars. There is nothing much for humans in this, save the proper reverence and filial fear that should be shown to the superabundant and astrological. Stay away, keep out, do not burn your wings and fall to the ground. The preceding image, the first emblem that our lawyer uses, is another image of Justice, after Chrysippus. ${ }^{70}$ Justitia, again sighted, has her breasts

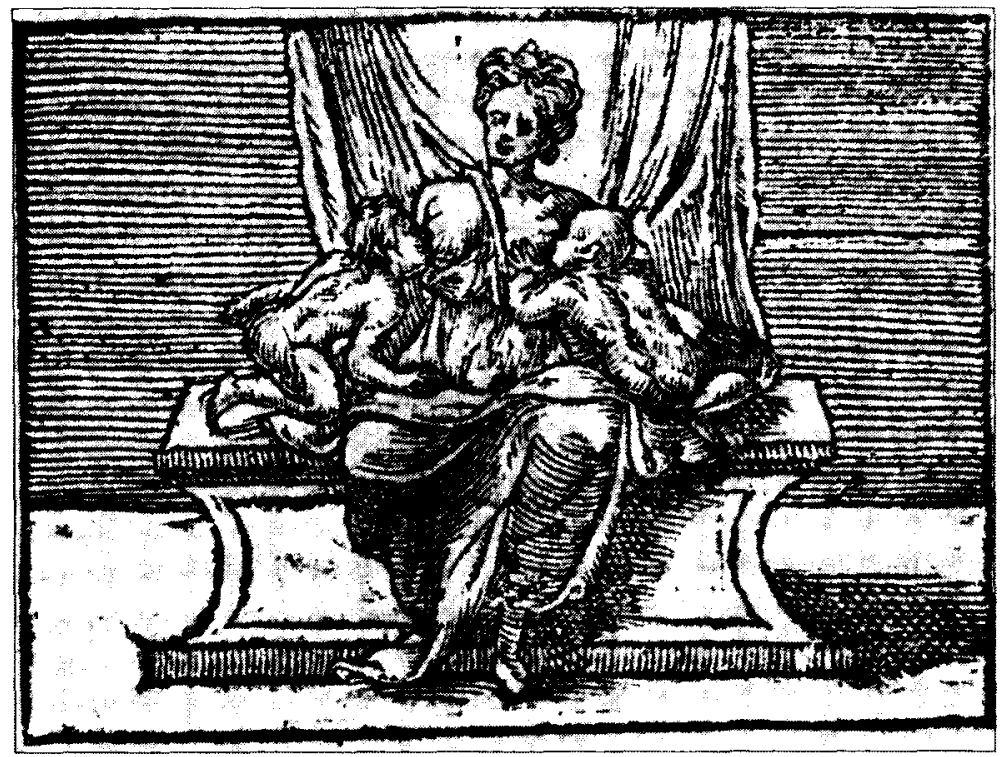

Figure 20. Emblem from Pegma: cum narrationibus philosophicis, Pierre Coustau, page a4r, 1555, Lyon, Matthias Bonhomme.

Reproduced courtesy of the Rare Book Collection, Lillian Goldman Law Library, Yale Law School.

exposed and is feeding twin babies. Justice is here a nursing mother, a loving parent, who on her right breast nurtures war and on her left feeds milk-knowledge, doctrine, hope--to law. She is seated on a bench, and behind her is a drape that frames the spectacle, a blindfold removed if you will. Justice suckles dependents and fosters dependency, infants who exist only in her shadow (umbraculis iustitiae), the supine and the acclamatory.

Returning then to Justitia and the blindfold that returns to cover the eyes of the Prince in a later emblem in Jurisprudentia, we can no longer

70. Figure 20. 
be in any doubt as to the political theology that this image conveys. The picture belongs squarely within iconomus, within the providential machinery of legal legitimacy and conveys in a relatively simple form a visible expression of a transcendent justice that cannot and should not be seen. Rex regnat sed non gubernat, the king rules but does not govern, according to one pertinent maxim. And the image of a blindfolded Justice does indeed signal in a fairly direct manner a divinity that will be of no help and will in essence do nothing. A Justice that exists in the heavens will not act in the world, as Coustau indicates in his earlier depiction after Nigidus. Humans must look to their own and do what is best, Coustau opines in his extrapolation of the image. Justitia exists within the domain of Deus otiosus and rex inutilis, an object of devotion and praise but not of any actual rule or extant oeconomy and administration. We might find her humorous really, as another ornamental divinity, except that, as I have argued, far from being useless, otiose in law-speak, she serves the legitimating function of holding the human down and keeping the supplicants, the peasants, out of the law and away from their future.

The political theology of the blindfold is suggestive simply of the religious sentiments and repression that this image unconsciously conveys. The fact that we now discuss this image in secularized contexts only serves to remind us that secularization displaces religious forces into earthly settings while leaving their power and sanctity intact. These are still liturgical images, solemnized and ceremonial legal trophies that generally stand on the facades of public buildings, on the pinnacles of courthouses, on the ceilings of legal rotundas, or engraved behind judicial thrones. The locations are points of the highest significance as instances of passage and entry, of first sight, and they are usually accompanied by intimidation and fear of the unfamiliar. Here is the immediate and visible aura of law, signifying a site of purity and consecration, of solemnity and ritual. It is equally an incomprehensible or enigmatic image of Justice, which even after the 668 pages in dual columns of Representing Justice, remains to be commented on further and reviewed again. What I have argued is that the blindfold marks a separation, a cleavage, that holds apart the human and the divine, the oeconomic and the iconomic, the mundane and the glorious. 
What next? What is sacred, according to a rather different tradition, should be profaned, made human, put to novel use. And what is separate should be conjoined. It is time, in other words, in different images, to be playful, foolosophical with Justitia. We need to be weened, made a little less dependent, a touch more irreverent, when it comes to justice and the politics of law. That surely is why the image of Justitia sighted appears first in the Foolosophy of la Perrière. The foolosophical is all to do with profanation, with making human, asserting authorship, and looking freely at the actual as opposed to the mythical sources of law. A final example from the Foolosophy, that great work of early French theory, an image of a blindfold being made, of Fortuna becoming an image. ${ }^{71}$ The figure shows a sculptor, the first image-maker, in doctoral robe and hat, chipping

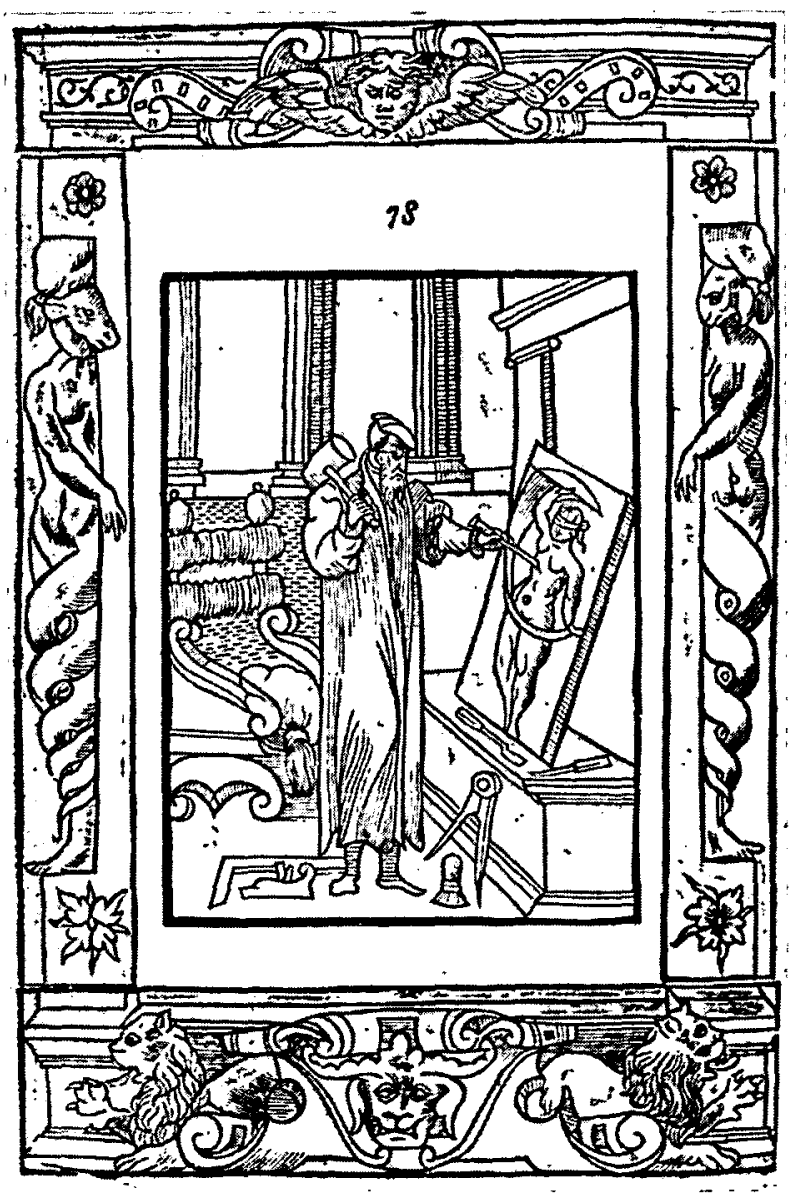

Figure 21. Emblem from La Morosophie, Guillaume de la Perrière, page 88,1555 , Lyon, Bonhomme.

Reproduced courtesy of the University of Glasgow Library, Special Collections.

71. Figure 21. 
with a chisel on a slab an image of Fortuna. The sculptor, the lawyer, the artificer makes the image and simultaneously shows that the image is blind. Fortuna is depicted naked, with her sail in her hand and a blindfold covering her eyes. She is the fool, but it is we that make her. Note also the staging of this image, the frame, which shows an angel directly above, winged and looking down. All things are visible to those non-beings whom we cannot see, the angels, the honored, the acclaimed. At the same time, to the side a human body with a goat's head and a serpent for a leg looks toward the image, the simulacrum. It is hardly incidental that the sculptor is poised to carve Fortuna's right breast, the mammary of war, whereas the left breast, that of law, has been formed. Beneath it are the tools of measurement and inscription. There could be hints here of the Amazon, the warlike women of mythology who removed their right breast

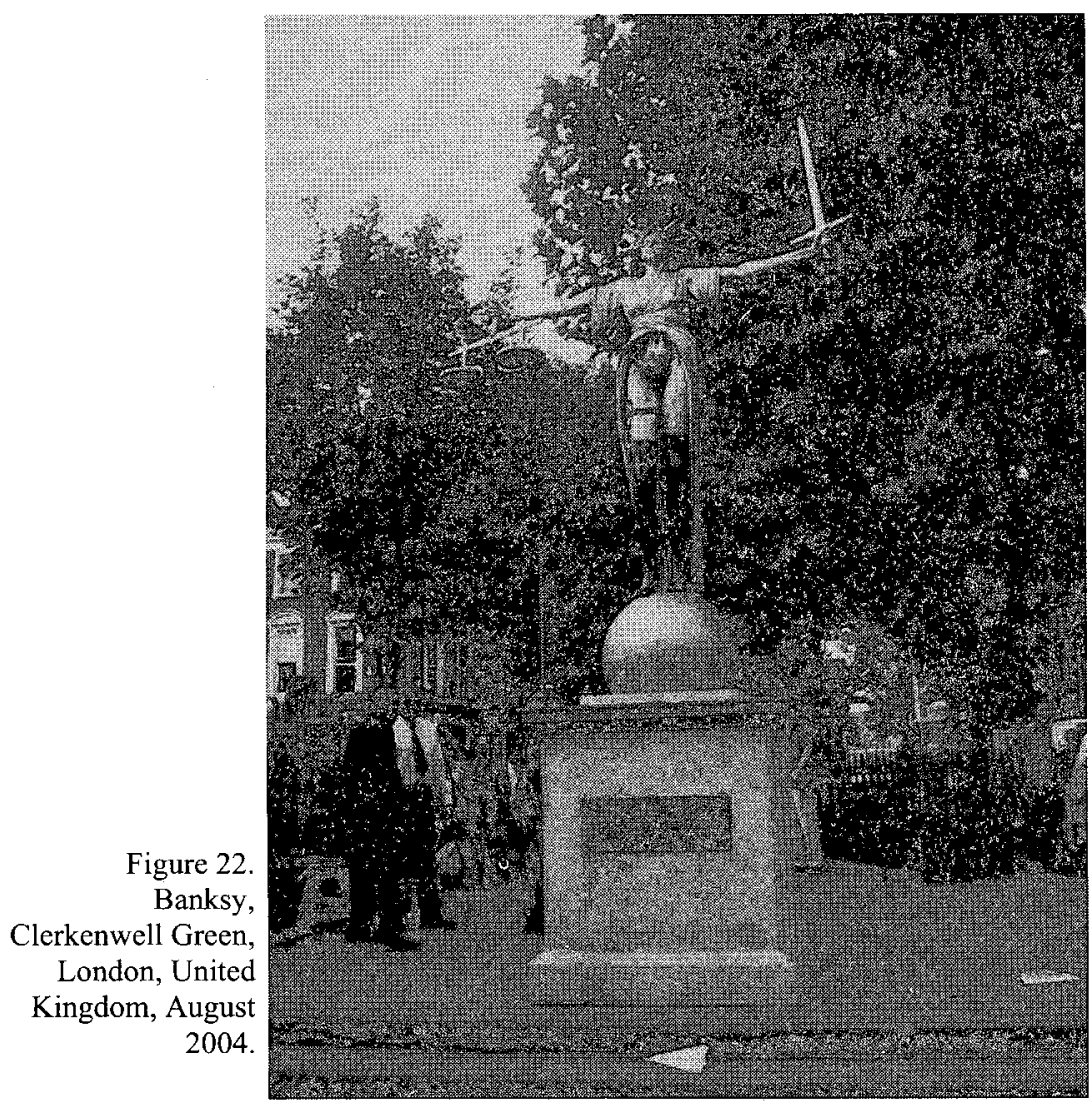

to be able to shoot their bow better, but the proper significance is that it is fate, the realm of administration, that is blinded and in need of rescue. We need, the Morosophie here depicts and paints, a better judge than chance, and a wiser law than fate.

It is time then to come to terms with the political theology of the 
blindfold on Justice and the accompanying wounds of lawyers. Time to move beyond the cold censure of images in Calvinism and to come up with our own imaginations. Images must be taken seriously precisely because they are the source of justice and the origin of the invention of law. The occasion of the visual in the legal, of visible laws, is that of renewing the tradition, that of making it ours first by understanding it and then by radicalizing it. In that spirit I could do worse than end with the work of a guerrilla artist who placed a three-and-a-half ton, twenty-foot tall statue of Justice in the heart of the city of London. ${ }^{72}$ Modeled on the statue of Justice that sits on top of the Old Bailey, Banksy offers a plebeian and irreverent image of Justice in a thong, with thigh high boots and a garter in which a dollar has been slipped. She has a blindfold as well, an eye-thong, one might say. I make no argument for the merits of the statue, only for the process and the form. It is foolosophical and offers the appropriate message: enough with the juridical hagiography; enough with the political theology that separates transcendent from immanent, acclamatory from practical, eyes from sight. The image of Justice is there simply and only to encourage participation, critical play, entry into rather than exclusion from the oeconomics of administration and government. The blindfold on Justitia is a forgotten reference to exclusion and to the accompanying though inarticulate mythology of law, of divine origin and hidden sources. It is our tradition, of course, and it needs to be learned and renewed, diagnosed and treated. Our common law is one that still silently manifests a belief in its own theogonic legitimacy, one that portrays in words the affect and effect of the indefinite time of the most antiquated and oldest of laws, of rules nascent beyond the memory of humanity. What is beyond memory should eventually be forgotten but in the positive sense of recollection and surpassing. You cannot forget what you do not know. You simply repeat it. It is only the process of recovering, reworking, and returning to images that allows for invention and novelty, foolosophy as creativity and play.

72. Figure 22. 